\title{
Natural Purification Through Soils: Risks and Opportunities of Sewage Effluent Reuse in Sub-surface Irrigation
}

\author{
Dominique M. Narain-Ford, Ruud P. Bartholomeus, Stefan C. Dekker, \\ and Annemarie P. van Wezel
}

\begin{abstract}
Contents

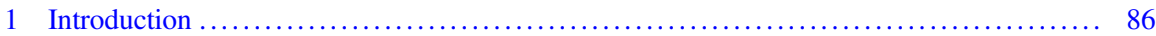

2 Policies and Guidelines Concerning Non-potable Water Reuse $\ldots \ldots \ldots \ldots \ldots \ldots \ldots \ldots \ldots .88$

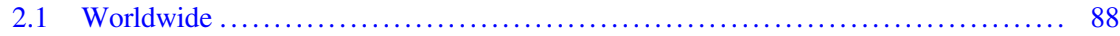

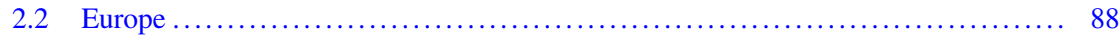

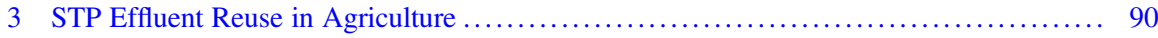

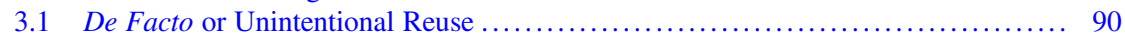

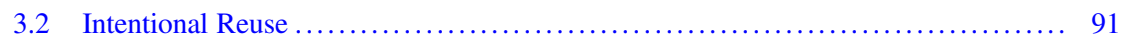

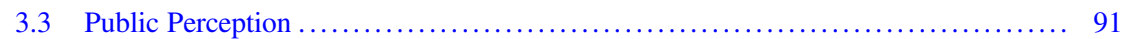

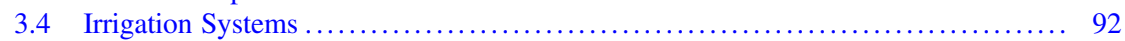

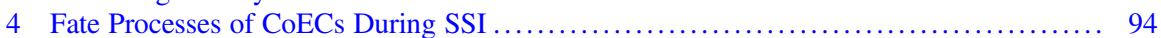

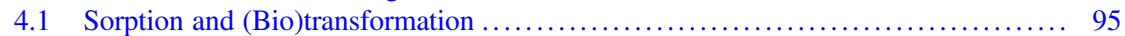

\section{M. Narain-Ford $(\bowtie)$}

Copernicus Institute of Sustainable Development, Utrecht University, Utrecht, The Netherlands Institute for Biodiversity and Ecosystem Dynamics, University of Amsterdam, Amsterdam, The Netherlands

KWR Water Research Institute, Nieuwegein, The Netherlands

e-mail: d.moncoeurnarainford@uva.nl

R. P. Bartholomeus

KWR Water Research Institute, Nieuwegein, The Netherlands

Soil Physics and Land Management, Wageningen University \& Research, Wageningen,

The Netherlands

e-mail: ruud.bartholomeus@kwrwater.nl

\section{S. C. Dekker}

Copernicus Institute of Sustainable Development, Utrecht University, Utrecht, The Netherlands

Department of Science, Faculty of Management, Science and Technology, Open University, Heerlen, The Netherlands

e-mail: S.C.Dekker@uu.nl

\section{A. P. van Wezel}

Institute for Biodiversity and Ecosystem Dynamics, University of Amsterdam, Amsterdam, The Netherlands

e-mail: a.p.vanwezel@uva.nl

P. de Voogt (ed.), Reviews of Environmental Contamination and Toxicology,

Volume 250, Reviews of Environmental Contamination and Toxicology, Volume 250,

https://doi.org/10.1007/398_2020_49 
4.2 Crop Uptake and Bioaccumulation ................................. 99

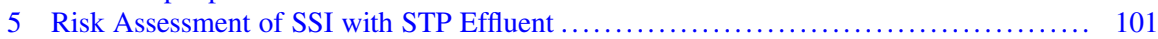

$5.1 \quad$ Exposure Assessment .............................................. 102

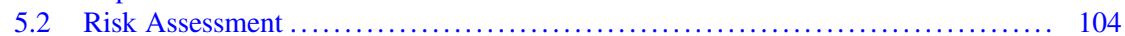

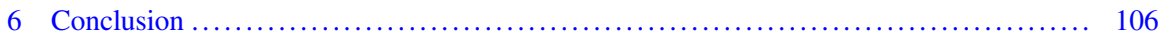

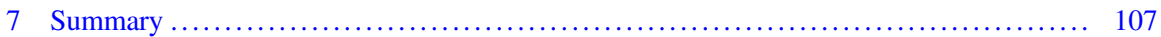

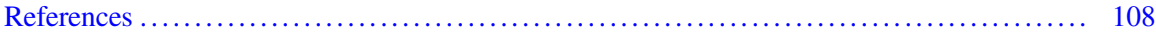

\section{Abbreviations}

$\begin{array}{ll}\text { CoEC(s) } & \text { Contaminant(s) of emerging concern } \\ \text { EC } & \text { European Commission } \\ \text { EU } & \text { European Union } \\ \text { FAO } & \text { The Food and Agriculture Organization of the United Nations } \\ \text { HQ } & \text { Hazard quotient } \\ \text { IARC } & \text { International Agency for Research and Cancer } \\ \text { ISO } & \text { International Organization for Standardization } \\ \text { IWA } & \text { International Water Association } \\ \text { OECD } & \text { Organization for Economic Cooperation and Development } \\ \text { PEC } & \text { Predicted environmental concentration } \\ \text { PNEC } & \text { Predicted no-effect concentration } \\ \text { PTMB } & \text { Persistent, toxic, mobile, or bio-accumulative } \\ \text { RQ } & \text { Risk quotient } \\ \text { SOM } & \text { Soil organic matter } \\ \text { SSI } & \text { Sub-surface irrigation } \\ \text { STP } & \text { Sewage treatment plant } \\ \text { TTC } & \text { Threshold of toxicological concern } \\ \text { UN-Water } & \text { United Nations Water } \\ \text { USEPA } & \text { United States Environmental Protection Agency } \\ \text { WHO } & \text { World Health Organization }\end{array}$

\section{Introduction}

Worldwide freshwater resources are under increasing stress, with a mismatch between demand and availability of water resources across both temporal and geographical scales (IWA 2018; UN-Water 2018). The main causes of freshwater resources being under stress are interlinked and include changes in water availability due to climate change, increases in water withdrawal for food security, and other economic activities. This was also analyzed with different socio-economic pathways indicating an increased global water withdrawal between 12 and $29 \%$ for 2050 compared to 2010 (Bijl et al. 2018), which will enhance prolonged dry periods (Chen et al. 2018). Increase in agricultural irrigation is currently one of the main global threats accounting for $69 \%$ of freshwater withdrawal (FAO 2016). This is not 
only an issue for arid regions with low rainfall and high population density that are prone to increasing water stress; also temperate areas with intense agriculture suffer from frequent non-potable freshwater shortages (Massoud et al. 2018; Voulvoulis 2018). Therefore, alternative water resources are explored in order to meet the current and future water demand.

Sewage treatment plant (STP) effluent may provide such an alternative freshwater source. Agricultural STP effluent reuse can compensate water shortages caused by seasonality or by irregular availability of other water sources for crop irrigation throughout the year. Furthermore, STP effluent contains many nutrients such as nitrogen, phosphorus, and potassium that can be used as fertilizer and save the cost of crop production (Jaramillo and Restrepo 2017). Irrigation with STP effluent is already used widespread, particularly in regions such as the Middle East, South and North Africa, and other Mediterranean countries, where the availability of freshwater is limited (Faour-Klingbeil and Todd 2018; FAO 2016; Khalid et al. 2018). Moreover, STP effluent is currently discharged in large volumes to surface water, including its contaminants of emerging concern $(\mathrm{CoECs})$, such as pharmaceuticals, metabolites, antimicrobial-resistant bacteria, and resistance genes (Council of the European Communities 2000). The load of these contaminants to surface water may however be reduced, due to soil passage and related sorption and (bio)transformation processes (Ghattas et al. 2017).

Controlled drainage systems allow to both prevent waterlogging and retain groundwater within agricultural parcels; groundwater levels and soil moisture conditions can be actively controlled (Ayars et al. 2006). Adding water to such a system turns it into an infiltration system, which is called sub-surface irrigation (SSI). The goal of SSI is to raise the groundwater level and improve the soil moisture conditions for plant growth through capillary rise. SSI systems can supply STP effluent to crops while the soil is used as a filter and buffer zone. Two major advantages that SSI via a controlled drainage system may have compared to sprinkling irrigation are that (1) there is no direct contact between fieldworkers and STP effluent lowering human health risks and (2) SSI could make optimal use of soil processes that minimize environmental occurrence and dispersion of CoECs (Hamann et al. 2016; Nham et al. 2015; van der Waals et al. 2018). Nevertheless, there are uncertainties concerning the environmental and public health implications which are associated with the reuse of STP effluent for SSI in agriculture. These are knowledge gaps pertaining (1) the fate of a broad range of CoECs during soil passage under field conditions including their transformation products $(\mathrm{Li}$ et al. 2014; Petrie et al. 2018), (2) the extent to which the dispersion of the mixture of CoECs is diminished and/or retained during SSI in agricultural fields (Christou et al. 2017a; Greskowiak et al. 2017), and (3) the adequate adaptation of current risk assessment tools for assessing both the possible opportunities and limitations of STP effluent water reuse (Baken et al. 2018; Christou et al. 2017b; Kase et al. 2018). The aim of this review paper is to collate recent knowledge on the risk and opportunities associated with the reuse STP effluent for sub-surface irrigation in agriculture. The knowledge gaps listed above will be discussed and highlighted. Additionally the policies and guidelines concerning non-potable water reuse on a global and 
European level will be presented. Finally, the review is enriched with concluding remarks and future perspectives of understanding the fate of CoECs in SSI with special emphasis on contaminants removal.

\section{Policies and Guidelines Concerning Non-potable Water Reuse}

\subsection{Worldwide}

At global level there are several guidelines, i.e., non-mandatory recommendations, available concerning water reuse (Table 1). In 2006 the World Health Organization (WHO) published guidelines on the safe use of wastewater, intended as a tool for decision-makers and regulators to provide a consistent level of health protection in different settings. The guidelines can be adapted for implementation under specific environmental, sociocultural, and economic conditions at a national level (WHO 2006). The United States Environmental Protection Agency issued the last version of the "Guidelines for Water Reuse" (USEPA 2012). These guidelines include a wide range of reuse applications (e.g., agricultural irrigation and aquifer recharge) and apply similar approaches as described by the WHO (2006) and the Australian Government Initiative (2006) for controlling health and environmental risks. The most recent global guidelines for STP effluent reuse in agricultural irrigation were published in 2015 by the International Organization for Standardization (ISO 2015). These ISO guidelines include water quality requirements for CoECs.

Remarkably, the State of California overtakes these global guidelines with specific regulations for CoECs (California Water Boards 2019). Consequently, these California water reuse regulations are being used as a global benchmark for the development of water reuse regulations worldwide. Noteworthy, California recently signed the Senate Bill No. 996 (Legislative Counsel Bureau 2018), which encourages communities to reuse STP effluent on-site.

\subsection{Europe}

At European level the need to address management of water resources to prevent scarcity and droughts was acknowledged in the EU's Blueprint to safeguard Europe's water resources (Table 1). In this Blueprint the need to use STP effluent as an alternative water resource for irrigation purposes is re-emphasized (European Commission 2012). Six EU Member States (Cyprus, Greece, Spain, France, Italy, and Portugal), all with (semi) Mediterranean climate, have requirements on water reuse in place in national legislation or in non-regulatory standards (Joint Research Centre 2017). Aquifer recharge (by surface spreading or direct injection) is only 
Table 1 Directives, policies, and guidelines related to water reuse

\begin{tabular}{l|c|c}
\hline & Standards \\
\cline { 2 - 3 } & Chemicals $^{\mathrm{a}}$ & Pathogens $^{\mathrm{b}}$ \\
\hline Worldwide & - & $\times$ \\
\hline $\begin{array}{l}\text { Guidelines for the safe use of waste water, excreta and greywater. } \\
\text { Vol. II Waste water use in agriculture (WHO 2006) }\end{array}$ & $\times$ & $\times$ \\
\hline $\begin{array}{l}\text { Guidelines for Water Reuse (USEPA 2012) } \\
\text { Guidelines for treated wastewater reuse (ISO 16075 2015) }\end{array}$ & $\times^{\mathrm{c}}$ & $\times^{\mathrm{c}}$ \\
\hline $\begin{array}{l}\text { Regulations Related to Recycled Water. Title 22, CDPH (2018) } \\
\text { (California). Draft amendment to the recycled water policy }\end{array}$ & $\times^{\mathrm{c}}$ & $\times^{\mathrm{c}}$ \\
\hline
\end{tabular}

Europe

Directive Nitrates (1991/676/EC) (Council of the European

Communities 1991)

Directive Urban Waste Water Treatment (1991/271/EC) (EEC

Council 1991)

Directive Water Framework (2000/60/EC) (Council of the European Communities 2000)

Regulation on the hygiene of foodstuffs (2004/852/EC) (European Commission 2004)

Regulation on laying down requirements for feed hygiene (2005/183/ EC) (European Parliament and the Council of the European Union 2005)

Regulation on microbiological criteria for foodstuffs (2005/2073/EC) (European Commission 2005)

Regulation on maximum residue levels of pesticides in or on food and feed of crop and animal origin (2005/396/EC) (European Parliament and the Council 2005)

Regulation setting maximum levels for certain contaminants in foodstuffs (2006/1881/EC) (European Commission 2006)

Directive on environmental quality standards in the field of water policy in order to meet the environmental quality standards for priority substances and certain other pollutants (2008/105/EC) (European Commission 2008)

Regulation Animal by-products and derived products (2011/142/EC)

(European Commission 2011)

Directive Groundwater (2014/80/EC) (European Commission 2014)

\begin{tabular}{|c|c|}
\hline$\times$ & - \\
\hline$\times$ & - \\
\hline$?$ & $?$ \\
\hline- & $\times$ \\
\hline$x$ & $\times$ \\
\hline- & $x$ \\
\hline$\times$ & - \\
\hline$x$ & - \\
\hline$\times$ & - \\
\hline- & $\times$ \\
\hline$\times$ & - \\
\hline
\end{tabular}

$\mathrm{x}$ yes

- no

? inconclusive

aThe heading "Chemicals" of the column in this table refers to standard measured indicator parameters such as biological oxygen demand (BOD), total suspended solids (TSS), and turbidity 'The heading "Pathogens" of the column in this table refers to standard measured indicator parameters such as E. coli, Legionella spp., and intestinal nematodes

${ }^{\mathrm{C}}$ Includes chemical contaminants of emerging concern or antimicrobial resistance

considered as a permitted use in Cyprus, Greece, and Spain (Drewes et al. 2017). Many of the standards developed at Member State level have been informed by the 2006 WHO Water Reuse Guidelines (WHO 2006), the ISO guidelines on safe use of STP effluent for irrigation use (ISO 2015), and regulatory approaches in other 
countries (e.g., California, Australia, and Israel) but also by specific national considerations such as environmental, sociocultural, and economic conditions.

In the Water Framework Directive (2000/60/EC) and the Urban Waste Water Treatment Directive (91/271/ECC), treatment of STP effluent is encouraged whenever appropriate to remove nutrients and organic material. One of the main barriers that the Blueprint recognizes for STP effluent reuse in the EU is a lack of common standards. Existing EU instruments for water reuse are listed in Table 1, which do not specify conditions for reuse. As the crops produced by SSI can be consumed by both animals and humans, instruments related to food quality and animal feed are also included in this table.

To overcome the abovementioned barrier, the Joint Research Centre (2017) selected a risk management framework to establish minimum quality requirements for water reuse in agricultural irrigation and aquifer recharge. The European Commission recently proposed a European regulation on minimum requirements for water reuse for irrigation (European Commission 2018). However, the proposed regulation is generic and provides a few minimum requirements, focused on general quality and public microbial health, but lacks minimum requirements for CoECs (Rizzo et al. 2018).

\section{STP Effluent Reuse in Agriculture}

It is useful to differentiate between de facto or unintentional reuse and intentional reuse. Both types of reuse can have significant socio-economic benefits but also institutional challenges and risks which require different management approaches (Rice et al. 2016).

\subsection{De Facto or Unintentional Reuse}

STP effluent is commonly indirectly reused in agriculture by irrigating with surface water in which STP effluent was discharged (Drewes et al. 2017). Conventional STPs are not optimized for the removal of CoECs, and their discharge will affect the receiving surface water quality (Blum et al. 2018; Grill et al. 2016; Jaime et al. 2018; Reemtsma et al. 2016; Sousa et al. 2017; Tran et al. 2018; van Wezel et al. 2018; Yang et al. 2017). During times of normal flow, this impact is less significant, but during low flow conditions with usually high irrigation demand, surface water can consist primarily out of effluent (Drewes et al. 2017; Fekadu et al. 2019; Munz et al. 2016; Roberts et al. 2016; Yadav et al. 2017). High flow conditions may also favor high impact of STP effluent, as during heavy rain sewer overflows will contribute to surface water contamination (Ccanccapa et al. 2016; Roberts et al. 2016). Water from these streams is in many cases directly applied to crops by sprinkler irrigation, resulting in potential exposure to human pathogens and organic micropollutants (Beard et al. 2019; Dulio et al. 2018; Munz et al. 2016; Schmitt et al. 2017; Thebo 
et al. 2017). For example, within the Llobregat river district (Spain), STP effluents were estimated to contribute between 8 and $82 \%$ to the total river flow (Drewes et al. 2017).

The risk associated with de facto STP effluent reuse might not be properly managed (Faour-Klingbeil and Todd 2018; Hong et al. 2018; Ncube et al. 2018; Nguyen et al. 2018). Where stream flows vary and the use of irrigation water is occurring only seasonally, the need to execute a comprehensive monitoring program of irrigation water with high frequency for CoECs monitoring parameters might not be obvious, feasible, or affordable. Therefore, to ensure the protection of human and the environment adequately, guidelines and minimum quality requirements for STP effluent are needed (Bieber et al. 2018; EurEau 2018; Rizzo et al. 2018; Sousa et al. 2017).

\subsection{Intentional Reuse}

Intentional reuse offers better control and management possibilities than de facto reuse. Planned non-potable water reuse requires that the treated effluent water quality is safe for crops and workers, and does not compromise local groundwater, surface water, or soil quality.

Many non-potable reuse applications (e.g., agricultural irrigation; cooling water) exhibit high seasonal dependencies, requiring either storage options or alternative reuse practices during off-season (Chen et al. 2018). While significant attention has been paid to more arid regions of the world, temperate climates also experience seasonal irrigation water shortages (Beneduce et al. 2017; Faour-Klingbeil and Todd 2018; Gude 2017; Voulvoulis 2018). Multiple planned reuse applications around the world demonstrated that the use of STP effluent for crop growth can be a safe practice (García-Santiago et al. 2017; Jaramillo and Restrepo 2017; Tal 2016). Intentional reuse has therefore become the norm in large parts of southern France, Spain, Portugal, Italy, Greece, and Cyprus (Drewes et al. 2017). According to Voulvoulis (2018), in $20062.4 \%$ of the total available treated effluent in the EU was reused for non-potable applications. Spain accounted for about a third of this (347 $\mathrm{Mm}^{3} /$ year), and Italy used approximately $223 \mathrm{Mm}^{3} /$ year. As minimum stream flow conditions are required for ecosystem functioning (Poff 2018), in some basins not all STP effluent can be reused for irrigational purposes (Drewes et al. 2017).

\subsection{Public Perception}

To promote intentional non-potable STP effluent reuse, possible public rejection to consume food irrigated with STP effluent needs to be understood (Massoud et al. 2018; Voulvoulis 2018). Public's distrust in authorities who are responsible for managing STP effluent is the result of fear in regard to (1) the level of human contact with the STP effluent; (2) the perceived dirtiness or filthiness; (3) increasing 
incidences of disease outbreaks (the "yuck factor"); (4) the lack of skilled labor and efficient management; (5) the cost of treatment, distribution, and the system; and (6) the amount of available freshwater for non-potable reuse (Massoud et al. 2018; Ricart et al. 2019; Smith et al. 2018).

Providing two-sided messages that present advantages and refute criticisms in order to justify the logic for the positive aspects of STP effluent reuse may aid in public acceptance. Better yet, providing information about the low risks of STP effluent reuse is more critical than communicating about the benefits of the water source (Price et al. 2015; Šteflová et al. 2018). One of the key challenges here is that trust, and efforts to build trust through public engagement, may ultimately be shaped by pre-cognitive reactions, i.e., the "yuck factor" (Garcia-Cuerva et al. 2016). Similarly, recent research has shown that awareness of existing unplanned (de facto) reuse practices has the potential to improve acceptance (Rice et al. 2016). This suggests that, rather than awareness of the need for STP effluent reuse as a solution to water supply issues, awareness of STP effluent reuse as an existing normal part of the water resource context, even in potable applications, may be a significant driver of acceptance (Smith et al. 2018). Thus, well-planned and wellexecuted water reuse programs and applying consistent risk-based standards for agricultural irrigation may have the potential to reduce the overall perceived risk while offering an alternative and sustainable water supply (Drewes et al. 2017; Gonzales-Gustavson et al. 2019).

\subsection{Irrigation Systems}

The environmental fate processes of the CoECs present in STP effluent and the exposure pathways to humans and the environment differ between various irrigation systems which are being used. Here we compare sprinkler irrigation, drip irrigation, and SSI (Table 2).

Table 2 Fate processes of CoECs in irrigation systems

\begin{tabular}{|c|c|c|c|c|}
\hline & \multicolumn{4}{|c|}{ Irrigation systems } \\
\hline & \multirow[b]{2}{*}{ Sprinkler } & \multicolumn{2}{|l|}{ Drip } & \multirow[b]{2}{*}{ Sub-surface } \\
\hline & & Surface & Sub-surface & \\
\hline Sorption & $\times$ & \multicolumn{2}{|c|}{$\times \times$} & $\times \times \times$ \\
\hline Photolysis & $x \times \times$ & $\times \times \times$ & $x \times$ & Insignificant \\
\hline (Bio)transformation & $\times$ & $\times$ & $\times \times$ & $\times \times \times$ \\
\hline Run-off & $\times \times \times$ & \multicolumn{2}{|c|}{ Insignificant } & Insignificant \\
\hline Volatilization & $\times \times \times$ & $\times \times \times$ & $x \times$ & Insignificant \\
\hline Crop uptake & $x \times \times$ & \multicolumn{2}{|c|}{$\times \times \times$} & $\times \times$ \\
\hline
\end{tabular}

Christou et al. (2019a), Gupta and Madramootoo (2017), Kibuye et al. (2019), Pepper and Gerba (2018)

$x \times \times$ Means process is prevailing compared to the other systems

$\times \times$ Means process is present in system, but not prevailing in comparison to the other systems

$\times$ Means process may be present in system 
In sprinkler irrigation STP effluent is supplied under pressure and segregated into particles or droplets of variable size and comes in direct contact with the aboveground parts of crops. The size of droplets determines the distance that the droplets will be transported through the air. As predicted by Stokes' Law, the smaller the droplet size, the further the droplets will be transported (Christou et al. 2019a; Gupta and Madramootoo 2017; Kibuye et al. 2019; Pepper and Gerba 2018). Sprinkler irrigation systems can be classified into two major types: (1) rotating head or revolving sprinkler system and (2) perforated pipe system, also referred to as "spray irrigation." The rotating head type consists of small-size nozzles on riser pipes fixed at uniform intervals along the length of the lateral pipe that are usually laid on the ground surface. The perforated pipe system is comprised of drilled holes or nozzles along the length through which water is sprayed under pressure (Mukherjee and Adhikary 2019).

Drip irrigation, which slowly applies STP effluent to individual points, can overcome the drawbacks of sprinkler irrigation by way of low energy requirements, not being affected by wind and preventing crop interception storage and evaporation losses (Gunarathna et al. 2017; Martínez and Reca 2014; Zapata et al. 2018). However, drip irrigation may perform poorly due to clogging of emitters (Gunarathna et al. 2017).

The application of STP effluent by means of SSI is less-time-variable then for sprinkler or drip irrigation. SSI has perforated or porous pipes buried in the soil and can sustain crops with high water requirements, as soil moisture content and groundwater are kept at desired levels (Siyal and Skaggs 2009). STP effluent seeps from the pipes into shallow groundwater by gravity and recharges it; thereupon soil capillarity provides the irrigation water to the crops (Fig. 1). Thus, in SSI as opposed to sprinkler and drip irrigation, CoECs are expected to primarily be removed via sorption and anaerobic transformation processes. Anaerobic transformation of CoECs is generally less energetically favorable than transformation under aerobic conditions. However, some aerobically recalcitrant CoECs can be

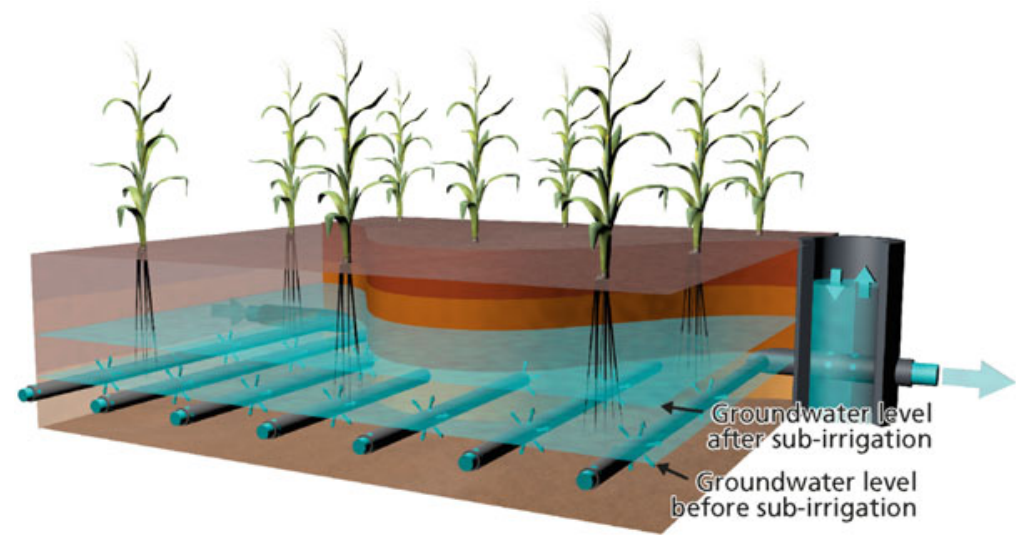

Fig. 1 Schematic overview of a sub-surface irrigation system 
bio-transformed under strictly anaerobic conditions, and little is known about the organisms and enzymatic processes involved in their transformation (Ghattas et al. 2017; Reemtsma et al. 2016).

In addition, SSI provides a soil barrier surpassing drip and sprinkler irrigation where the STP effluent comes in direct contact with the crops (Ghattas et al. 2017; Hamann et al. 2016; Nham et al. 2015; van der Waals et al. 2018). Furthermore, using SSI as a method of supply can decrease CoECs owing to filtration and buffer functions of soil. These functions are the result of fate processes, i.e., sorption- and (bio)transformation-related processes, which CoECs endure during soil passage in SSI systems. The efficiency of SSI may be affected by the hydrological boundary conditions and soil type which determine the extent of deep percolation water losses, the water application rate, and design parameters such as the size, depth, and spacing of pipes (Ayars et al. 2015; Martínez and Reca 2014; Bonaiti and Borin 2010). Ergo, the fate of CoECs present in STP effluent is highly dependent on the method of supply (Ricart et al. 2019).

Be that as it may, not all soils are suitable for SSI, i.e., to retain irrigated water in the rhizosphere. Suitable soils typically consist of a permeable top soil to allow water to infiltrate and a resistant layer below the drainage/infiltration tubes to prevent quick losses due to deep percolation (Benard et al. 2016; Shakir et al. 2017).

Independent of the irrigation method, using STP effluent for irrigation on soils with a high clay content may deteriorate the soil quality (Rengasamy 2018).

\section{Fate Processes of CoECs During SSI}

Environmental fate of CoECs during soil passage in SSI will be affected by sorption and (bio)transformation processes and crop uptake (Gillefalk et al. 2018; Nham et al. 2015). These fate processes are affected by the intrinsic properties of CoECs, such as hydrophobicity, charge, ionization state, structure and molecular weight, as well as the extrinsic parameters of the system, such as residence times, cation exchange capacity, $\mathrm{pH}$, temperature, and the structure of microbial communities (Arp et al. 2017; Ren et al. 2018; Schulze et al. 2018, 2019). Furthermore, the abovementioned fate processes will determine the bioavailability of the CoECs. For most CoECs, the freely dissolved concentration is closely related to the risk of the contaminants, because only this concentration equilibrates with the internal tissue concentration that initiates a toxic effect (Cipullo et al. 2018).

The environmental fate processes, which in SSI systems will occur to a large extent under anaerobic conditions, can also be observed in other systems such as vertical flow constructed wetlands, river bank filtration, and managed aquifer recharge (Gorito et al. 2017; Hamann et al. 2016; Nham et al. 2015; Petrie et al. 2018). Horizontal flow constructed wetlands also offer insight into these primarily anaerobic processes; however here the transport medium is water instead of soil (Wagner et al. 2018). As experimental data on CoECs fate processes for SSI are largely lacking, we will review the soil processes in the other aforementioned 
constructed wetland, river bank filtration, and managed aquifer recharge systems. In the following sections, studies concerning these main environmental fate processes which will occur during SSI are reviewed.

\subsection{Sorption and (Bio)transformation}

In water treatment applications, soil passage has proven to have the ability to filter CoECs from STP effluent as a result of sorption and (bio)transformation processes (Bertelkamp et al. 2014; Hamann et al. 2016; Nham et al. 2015). Sorption is typically quantified by an equilibrium organic carbon-water partition coefficient $\left(K_{\mathrm{oc}}\right)$, defined as the ratio of the concentration in soil or sediment organic carbon $(\mathrm{mg} / \mathrm{kg})$ vs. the concentration in surrounding water $(\mathrm{mg} / \mathrm{L})$ at equilibrium (Arp et al. 2017). The terms transformation or degradation refer to structural modification of an organic chemical (primary transformation) or its complete breakdown to $\mathrm{CO}_{2}$ and water (ultimate transformation) (Poursat et al. 2019). The degree to which an organic CoEC will react to its environment is dependent on its intrinsic and extrinsic characteristics (Schulze et al. 2019). These will be discussed in the below-mentioned paragraphs and are summarized in Table 3.

\subsubsection{Intrinsic Properties of Organic CoECs}

The intrinsic properties of CoECs greatly affect their occurrence and behavior in the environment. Their complexity, i.e., long structures, ionic strength, and the presence of functional groups, determines the rate at which they are transformed and subsequently mineralized (Ghattas et al. 2017). These intrinsic characteristics, including

Table 3 Factors that influence sorption and (bio)transformation of CoECs during soil passage

\begin{tabular}{l|l}
\hline \multirow{4}{*}{ Intrinsic } & Hydrophobicity \\
\cline { 2 - 2 } Extrinsic & Functional groups \\
\cline { 2 - 2 } & Charge \\
\cline { 2 - 2 } & Ion-strength \\
\cline { 2 - 2 } & Structure length \\
\hline & Time and continuity of irrigation \\
\hline & Volume of effluent versus volume of soil \\
\hline & STP effluent matrix \\
\cline { 2 - 2 } & Organic matter \\
\cline { 2 - 2 } & Residence times \\
\cline { 2 - 2 } & Microbes \\
\cline { 2 - 2 } & pH \\
\hline & Redox conditions \\
\cline { 2 - 2 } & Seasonal temperature variations \\
\hline & Concentration of competing ions \\
\hline
\end{tabular}


standard test protocols, are well described for target and suspect compounds in Sjerps et al. (2016), PubChem, ChemSpider, Stoffident, and Toxnet (NORMAN 2019). New treatment processes, such as reverse osmosis coupled with advanced oxidation, achieve high removal efficiency toward pharmaceutical products and other CoECs (Albergamo et al. 2019; Luo et al. 2014; Magdeburg et al. 2014; Pan et al. 2019). Their implementation is however strongly impeded by high operation and maintenance cost, and they may not be feasible to treat large volumes of STP effluent at low CoECs concentrations (Pan et al. 2019). Accordingly, significant interest continues to grow in the most efficient, feasible, and environmentally friendly approaches for the transformation of CoECs (Bilal et al. 2019). This includes the induction of microbial adaptation (Poursat et al. 2019), which will be discussed in the next section.

\subsubsection{Extrinsic Properties of Organic CoECs}

Besides microbial adaptation, redox conditions, organic matter, residence times, and seasonal temperature variations make up the aforementioned environmental conditions of the SSI system that influence the fate of organic CoECs in SSI systems.

\section{Redox Conditions}

The oxygen demand exerted by the incoming STP effluent exceeds the amount of oxygen available within the SSI system. Therefore, anaerobic pathways will become an important mechanism for removal of CoECs (Arden and Ma 2018; Kahl et al. 2017; Petrie et al. 2018). Under anaerobic conditions, extracellular respiration bacteria oxidize electron donors (organic matter) and transport electrons to exogenous electron acceptor, by which the microorganisms can grow (Peng et al. 2016; Ren et al. 2018). The transformation of CoECs is based on the presence of microorganisms with specific catalytic activities targeting certain functional moieties in the compound. Thus, organic CoECs have the potential to serve as substrates or electron acceptors for anaerobic microorganisms in SSI (Ghattas et al. 2017). For example, compounds with ether moieties (especially methyl-aryl-ethers) and iodinated aromatic compounds (e.g., iodinated X-ray contrast media as well as their aerobic transformation products) were reported by Ghattas et al. (2017) to be prone to anaerobic transformation.

\section{Organic Matter}

The sorption potential of soils is positively correlated to the amount of organic matter. However, soils with the same organic matter content may have different sorption potentials for CoECs, depending on the soil organic matter (SOM) structure (aromaticity and aliphaticity) at nanoscale, such as polarity, spatial arrangement, and 
physical conformation (Mao et al. 2019; Ren et al. 2018). In SSI, sorption is expected to have a larger effect compared to other irrigation systems, as the STP effluent is introduced into the saturated soil. Highly specific surface areas in the saturated soil enable colloids to effectively sorb hydrophobic contaminants (Quesada et al. 2019; Ren et al. 2018). In addition, electrical characteristics of SOM can induce electrical attraction with positively charged chemical compounds (Park et al. 2018), decreasing their bioavailability. Soil pH determines the surface charge of SOM and minerals, and the existing forms of CoECs, which have significant impact on charge-dependent adsorption process (Arp et al. 2017). Consensus is lacking on which domain of SOM dominates sorption, probably caused by different types of SOM used in different experiments (Jin et al. 2015; Quesada et al. 2019; Ricart et al. 2019; Tran et al. 2017). Furthermore, dissolved organic matter may contribute to the movement of microbes (Ren et al. 2018).

\section{Residence Times}

Prolonged exposure of soils to STP effluent can also cause CoECs to form strong bonds to soil, i.e., aging, consequently causing a decline in bioavailability (Brunsch et al. 2018; Ren et al. 2018). For ionizable substances, sorption is quantified with the $\mathrm{pH}$-dependent organic carbon-water distribution coefficient $\left(D_{\mathrm{oc}}\right.$, dependent on the dissociation constant or $\mathrm{p} K \mathrm{a}$ of the specific chemical), accounting for the total sum of neutral and charged species sorbed and dissolved (Arp et al. 2017). For positively charged ionic and ionizable molecules, there are other interactions that can decrease mobility in the environment that are not accounted for with $D_{\text {oc }}$ or the solubility in water $\left(S_{\text {water }}\right)$ alone, such as cationic or anionic exchange interactions to minerals and other surfaces or precipitation with counter-ions. Thus, in the absence of accounting for such additional interactions, basing mobility on $\mathrm{pH}$ dependent $D_{\mathrm{oc}}$ or $S_{\text {water }}$ represents a maximum assumption for mobility (Schulze et al. 2018). Accordingly, prolonged sorption may lead to microbial responses such as the formation of biofilms (Adrion et al. 2016; Bezza and Chirwa 2017; Singleton et al. 2016). Biofilms can reach thicknesses of multiple centimeters. This results in limited oxygen diffusion to the inner parts, which consequently leads to an oxygen gradient within the biofilm; in other words both aerobic and anaerobic transformation processes are made possible (Wagner et al. 2018). In constructed wetlands the presence of biofilms is identified as a key removal mechanism (Gorito et al. 2017; Kahl et al. 2017; Petrie et al. 2018). It can be expected that the prolonged exposure of croplands to STP effluent during SSI will also induce the formation of biofilms. This may limit the infiltration capacity of the SSI system. However, when groundwater is not fed by STP effluent, it has the potential to decrease below desired levels, leading to deterioration of the formed biofilms. 


\section{Seasonal Temperature Variations}

Most adsorption reactions in soil are spontaneous and exothermic processes, resulting in a decrease in the adsorption extent with higher temperatures (Lamichhane et al. 2016). Kahl et al. (2017) studied the effect of design and operational conditions on the performance of subsurface flow treatment wetlands, with CoECs as indicators. Six pilot-scale subsurface flow treatment wetlands loaded with primary STP effluent were monitored over one year. The results from this study suggested that in horizontal flow constructed wetlands, biotransformation is the major removal process during high temperature seasons, while sorption in the rhizosphere and crop uptake might be more prevalent during cold-low temperature seasons (Gorito et al. 2017; Kahl et al. 2017; Petrie et al. 2018). Notwithstanding, this is highly dependent on the intrinsic characteristics of the CoECs (Arp et al. 2017). Thereupon, it can be inferred that in SSI systems, biotransformation may also be the major removal process of organic CoECs during the growing season, while sorption may take on a more significant role during cold temperature seasons.

\section{Microbial Adaptation}

Besides the formation of biofilms, long-term exposure of microorganisms to CoECs can alter the microbial community structure and result in a higher resistance to CoECs and an improved potential for biotransformation.

\section{Microbial Resistance to CoECs}

Direct evidence indicating the impact of CoECs on the microbial resistance in the agricultural environment as a result of STP effluent SSI irrigation is scarce and controversial. One (Cycon et al. 2019) refers to the fact that soil contains a high abundance of bacteria that compete to survive, which means that even if STP effluent-derived bacteria accumulate in the soil, it may take several decades to produce noticeable effects, while another states that the continuous release of antimicrobial-resistant bacteria and genes could create a potential reservoir for antimicrobial resistance (Christou et al. 2017a; Larsson et al. 2018; Manaia 2017).

\section{Enhanced Biotransformation}

Biotransformation of CoECs can be enhanced through induction of microbial adaptation. Microbial community adaptation is controlled by three mechanisms: (1) microbial interactions within the community and governed by microbial ecology concepts, (2) the genetic information that controls the functional potential of the whole community, and (3) the interplay between the microbial community and the environment. At the level of the individual cell, adaptation can refer either to phenotypic or genetic adaption (Poursat et al. 2019). Several studies have described the adaptation of microorganisms to chemical stressors, which they then use as energy sources, i.e., growth-linked transformation, or acquire the ability to 
co-metabolize (Campa et al. 2018; Poursat et al. 2019; Wagner et al. 2018; Winkler et al. 2019). In addition, microbes can make a series of adjustments to environmental changes (limited bioavailability of chemicals), involving morphological, physiological, and behavioral adaptation. Behavioral adaptation can positively influence the transformation rate of CoECs; however, it may also lead to an increase in microbial resistance (Bertelkamp et al. 2016; Christou et al. 2017a; Otto et al. 2016; Poursat et al. 2019; Ren et al. 2018). The greatest uncertainty concerning the complex process of microbial adaptation is estimating the time required for adaptation to a new molecule on the one hand and the parameters that promote the adaptation process on the other hand (Poursat et al. 2019). However the review by Poursat et al. (2019) showed that adaptation can be induced under certain laboratory conditions, even with persistent or inherently biodegradable compounds. Among all techniques used to trigger adaptation events, pre-exposure of microorganisms present in the soil of croplands to STP effluent before cultivating crops seems to be the best candidate to optimize the biotransformation in SSI (Poursat et al. 2019; Reid et al. 2020; Wang et al. 2020).

\subsection{Crop Uptake and Bioaccumulation}

Numerous studies, mainly conducted under controlled conditions, highlighted that crops exposed to known concentrations of individual or cocktails of CoECs through irrigation with STP effluent uptake and accumulate these contaminants in their tissues, in the range of low $\mu \mathrm{g} / \mathrm{kg}$ to low $\mathrm{mg} / \mathrm{kg}$ (Christou et al. 2019b). In SSI systems, the uptake of CoECs by crops is largely dependent on their bioavailability in soil pore water near the rhizosphere, driven by their intrinsic and extrinsic properties (Christou et al. 2017a; Goldstein et al. 2014). This paragraph will focus on these intrinsic and extrinsic properties.

\subsubsection{Intrinsic Properties of Organic CoECs}

Root uptake of most organic CoECs is passive. The mechanisms of CoECs uptake by crops are driven by the transpiration derived mass flow and largely dependent among others on the intrinsic properties of the compounds, especially their hydrophobicity, chemical structure, and charge (Christou et al. 2017b; Goldstein et al. 2014; Miller et al. 2016). For neutral compounds hydrophobicity is one of the key transport factors, whereas for ionizable CoECs the movement and distribution also depend on the dissociation constant $(\mathrm{pKa})$, charge of the chemical, and $\mathrm{pH}$ of the various crop compartments. Thus, the electrical attraction or repulsion of ionizable CoECs to the negatively charged root surface and ion trap effects may affect their accumulation in roots (Christou et al. 2019b). The ionic trapped CoECs are expected to be translocated preferentially in the phloem rather than in the xylem and as opposed to the nonionic CoECs, be accumulated in the fruit rather than in the leaves (Goldstein et al. 2014). During transport within the crop, organic CoECs can be 
metabolized and sequestered within various crop tissues. Crops contain enzymatic systems such as cytochrome P-450s and their (bio)transformation capacity may be compound as well as crop specific. Non-ionizable, polar, highly water-soluble organic compounds are most likely to be taken up by crops and translocated to shoot tissue (Doucette et al. 2018).

\subsubsection{Extrinsic Properties of Organic CoECs}

The extrinsic properties of CoECs which determine their bioavailability in SSI systems are environmental conditions such as the amount of oxygen, $\mathrm{pH}$, and temperature that crops are exposed to.

Growing on well-aerated soils, contrary to partially or non-aerated ones, such as waterlogged soils, may facilitate the uptake of CoECs by crops (Christou et al. 2019b). CoECs in their ionic form, which is predominant in soils with $\mathrm{pH}$ higher than the $\mathrm{pKa}$ of the compound, have a lower potential for crop uptake, due to repulsion forces exerted by the negatively charged root epidermis. Similarly, soils with acidic $\mathrm{pH}$ values (e.g., soil $\mathrm{pH}<$ compound $\mathrm{pKa}$ ) may result in the presence of contaminants in their neutral form (high fraction of neutral molecules $(f n)$ values), thus facilitating their uptake (Goldstein et al. 2014; Miller et al. 2016). Remarkably, the $\mathrm{pH}$ in different crop organelles (vacuole, xylem, phloem, and cytosol) may differ from each other and from the $\mathrm{pH}$ in the irrigation water. Therefore, compounds taken up easily do not necessarily distribute well within crops. Compounds that are neutral within a wide range of $\mathrm{pH}$ such as carbamazepine and caffeine have been proven to cross membranes easily (Riemenschneider et al. 2016).

Drought stress, implying dry climatic conditions and limited water availability, also affects the uptake of CoECs by crops, independent of the method of supply. Crops such as bananas, citrus, fruit trees, walnut (fruit trees), cucumber, eggplant, green beans, melons, pepper, tomatoes (vegetable crops), peanuts, and alfalfa (arable crops) have a higher potential for CoECs uptake when grown in hot and dry conditions (thus irrigated in short intervals). Seasonal crops that are growing during the summer period (i.e., vegetables) and crops grown in greenhouses irrigated with STP effluent, as well as perennial crops for which STP effluent irrigation is practiced all year round for a prolonged period (i.e., fruit trees), may also be categorized as crops with high potential for CoECs uptake. On the contrary, crops grown during the autumn and winter period, where irrigation with STP effluent is irregularly practiced because of the precipitation events, as well as succulent crops (i.e., agave, aloe vera), may be categorized as crops with the lowest potential for CoECs uptake (Zhang et al. 2016). Noteworthy, leafy vegetables (i.e., lettuce, spinach, cabbage, broccoli, celery, etc.), often cultivated intensively all year round (thus irrigated), may accumulate greater concentrations of CoECs in their edible tissues (Christou et al. 2019b). With SSI a combination of the abovementioned extrinsic factors that influence crop uptake is at play.

Independent of the method of supply, other environmental factors, like ambient temperature, wind speed, and air humidity, may also affect crop uptake of CoECs by 
shaping their evapotranspiration rate, and therefore their water uptake (Christou et al. 2019b). Accordingly, it can be expected that SSI compared to other irrigation systems, where the total amount of irrigated STP effluent comes in direct contact with either the above or below ground parts of crops, minimizes crop uptake by reducing the amount of effluent that comes in direct contact with the roots through capillary rise. In SSI this is achieved as a result of STP effluent seeping from the pipes into shallow groundwater and subsequently lowering CoECs their bioavailability due to sorption and anaerobic (bio)transformation processes. Yet, aerobic conditions which are present in the rhizosphere may also affect the bioavailability of CoECs to crops. These are issues poorly understood, but the current knowledge cannot exclude the possibility of CoECs uptake by crops in SSI systems.

Only few studies followed an experimental setup where real STP effluent was applied for irrigation of crops in field, representing actual farming practices. Moreover, even fewer studies have reported concentrations of the studied CoECs in both the growing medium (i.e., soil) and the edible tissues of the crops, thus allowing for the estimation of the bioconcentration factor (Christou et al. 2017b, 2019a, b; Franklin et al. 2015; Goldstein et al. 2014; Pan et al. 2014; Picó et al. 2019; Riemenschneider et al. 2016). For example, Goldstein et al. (2014) reported that the concentration of CoECs in cucumber and tomato leaves of crops grown in three different soils in pots was of similar order, whereas their concentration in the tomato fruit was much lower compared to that in the cucumber fruit. This was attributed to differences in fruit physiology and specifically to the fact that cucumber fruits exert physiological responses and functions similar to those of leaves, as the chlorophyll content of the exocarp and the efficiency of photosystem II of fruits are similar to that of leaves (cucumber fruits transpire water while also facilitating the direct fixation of atmospheric $\mathrm{CO}_{2}$ and recapturing of respired $\mathrm{CO}_{2}$, contributing to fruit growth). Riemenschneider et al. (2016) observed that the concentration of CoECs in fruits increased with the increasing duration of STP effluent irrigation, reaching the highest concentration values during the last harvest of the third year of the study. The overall concentration showed the following decrease of order: roots $>$ leaf $>$ shoot $>$ fruit, which may have been due to the limited distribution of ionic compounds in aerial crop organs. It is worth noting that generally the sum concentration of micropollutants decreased in the order of leaf $>$ root $>$ fruit-bearing vegetables (Christou et al. 2017b; Riemenschneider et al. 2016).

\section{Risk Assessment of SSI with STP Effluent}

A variety of CoECs are present in STP effluent, and their mixtures vary intra- and inter-daily, seasonally, and inter-annually (Petrie et al. 2015; van Wezel et al. 2018). Reuse of STP effluent may result in exposure of croplands to a large group of compounds that are not commonly monitored, for which there is scarce information on possible effects, and for which no regulatory criteria or quality standards exist while they potentially might pose risks (Halden 2015; Rizzo et al. 2018). 
Any concern about health or environmental risks of SSI based on STP effluent reuse might hinder its acceptance (Rice et al. 2016). Therefore a better understanding is needed on environmental fate processes of the CoECs and their exposure pathways to humans and the environment during SSI for an adequate risk assessment.

\subsection{Exposure Assessment}

Within the risk assessment process of STP effluent reuse in SSI, a critical step is the identification of the exposure pathways, including their magnitude, frequency, and duration (Klaassen 2008). There are various ways in which contaminants can move from the source through media to points of exposure in a sub-surface irrigation system (Fig. 2). Although the vast majority of CoECs present in STP effluent are in

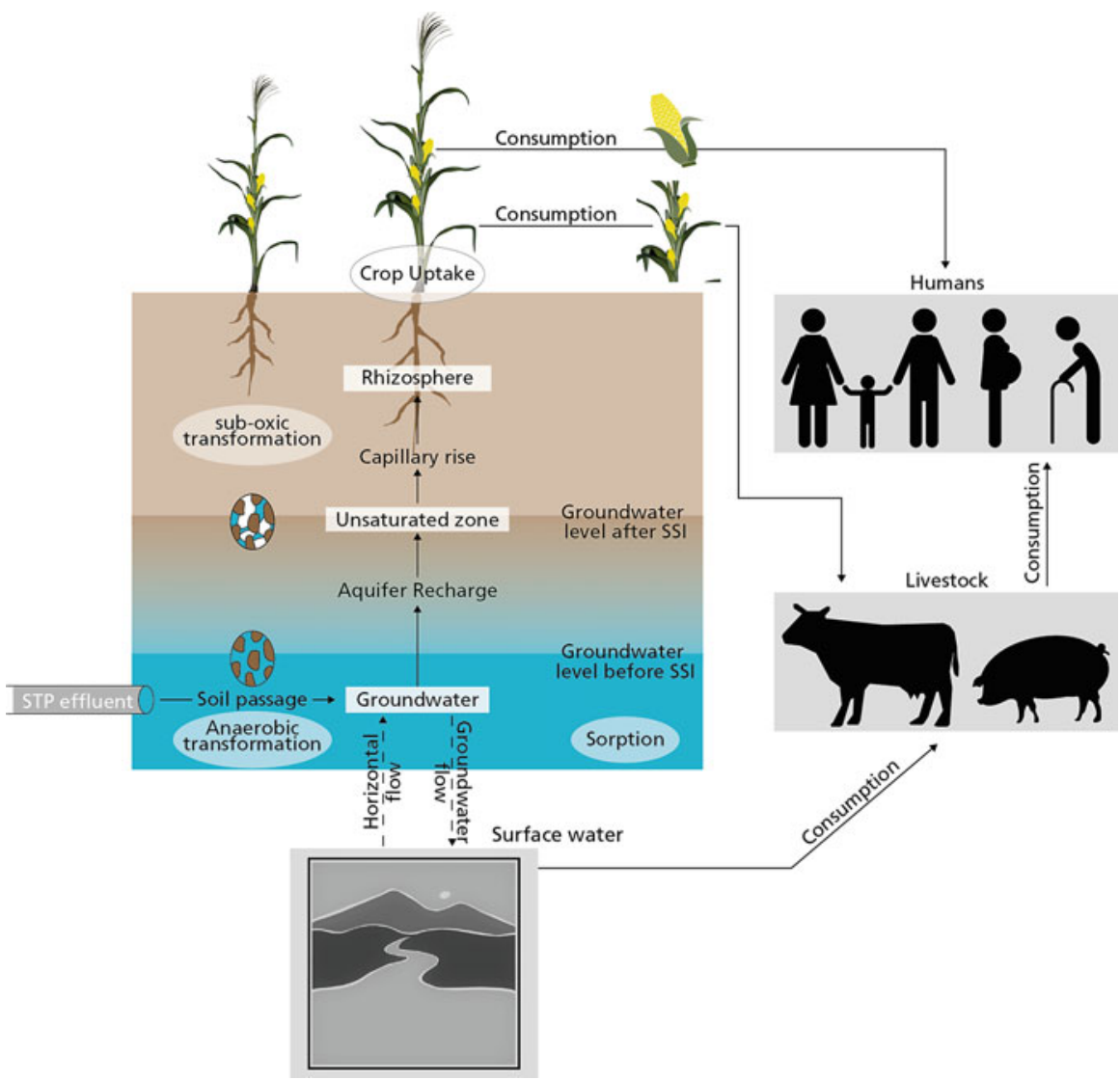

Fig. 2 The exposure routes of STP effluent in a SSI system. The dashed lines represent additional pathways to the primary route (bold lines) 
the low ng per liter range, many of these compounds can raise environmental and human health issues (Nohmi 2018; Reemtsma et al. 2016).

Few studies have assessed the long-term opportunities and limitations of the most environmentally relevant compounds. These are compounds that are used and produced in significant quantities and are persistent, toxic, mobile, or bio-accumulative (PTMB) (ECHA 2017; Reemtsma et al. 2016). One essential difficulty in conducting risk assessments for highly mobile substances is that techniques to measure these substances are sparse and new methods are emerging (Albergamo et al. 2019; Gago-Ferrero et al. 2018; Sjerps et al. 2016). Transformation product monitoring of PTMB compounds remains challenging as most of them are so-called unknown unknowns, that is, compounds of which the structure is unknown and which are not present in chemical databases. Indeed, liquid chromatography-mass spectrometry technology has been one of the most competitive areas over the last two decades in terms of instrumental development, with advances in the speed and the sensitivity of analysis. State-of-the-art instruments now allow ultra-trace multiresidue analysis with hundreds of chemicals being measured in a single run, even after a simple direct injection of an aqueous sample (Brunner et al. 2019; Hollender et al. 2017; Reemtsma et al. 2016). Another important development is the popularization of high resolution MS (HRMS) analyzers, which has been a huge step for the identification of transformation products of organic CoECs as well as for the screening of unknown substances (Brunner et al. 2018, 2019). Therefore, many of these CoECs may already be in the environment, going unnoticed (Arp et al. 2017; Gago-Ferrero et al. 2018; Kase et al. 2018; Schulze et al. 2019). Apart from occurrence in effluent samples, prioritized compounds should fill all of the PTB cut-off values from Table 4.

For this purpose five CoECs that are known to be present in STP effluent are assessed: carbamazepine, paracetamol, perfluorooctanoic acid, sulfamethoxazole, and triclosan (Delli Compagni et al. 2020; Fraz et al. 2019; García-Santiago et al. 2017). These CoECs cover a broad range of physicochemical properties in terms of air/water partitioning coefficient $\left(K_{\mathrm{aw}}\right)$, normalized organic carbon partitioning

Table 4 PTB cut-off hazard classification criteria according to Annex XIII, REACH

\begin{tabular}{|c|c|c|}
\hline Property & \multicolumn{2}{|l|}{ PBT-criteria } \\
\hline Persistence & $\begin{array}{l}\text { Fresh- or estuarine water: } \\
\text { Marine water: } \\
\text { Marine sediment: } \\
\text { Fresh- or estuarine sediment: } \\
\text { In soil: }\end{array}$ & $\begin{array}{l}t^{1} /_{2} \text { (half-life) }>40 \text { days } \\
t^{1} /_{2}>60 \text { days } \\
t^{1} /_{2}>180 \text { days } \\
t^{1} /_{2}>120 \text { days } \\
t^{1} /_{2}>120 \text { days }\end{array}$ \\
\hline Toxicity & \multicolumn{2}{|c|}{$\begin{array}{l}\text { - A ratio of predicted environmental concentration to predicted no-effect } \\
\text { concentration (PEC/PNEC) } \geq 0.01 \\
\text { - Classified as carcinogenic, germ cell mutagenic, or toxic for reproduction } \\
\text { - There is other evidence of chronic toxicity, as identified by the classifi- } \\
\text { cations: Specific Target Organ Toxicant (STOT) }\end{array}$} \\
\hline Bioaccumulation & \multicolumn{2}{|c|}{ Bioconcentration factor $(\mathrm{BCF})>2,000$} \\
\hline
\end{tabular}

Arp et al. (2017), ECHA (2017) 
Table 5 Physiochemical properties of selected CoECs

\begin{tabular}{l|l|l|l|l}
\hline CoEC & $\begin{array}{l}\text { Chemical } \\
\text { classification }\end{array}$ & $\mathrm{pKa}(\mathrm{p} K \mathrm{~b})^{\mathrm{a}}$ & $\begin{array}{l}\log D \\
(\mathrm{pH}=7)^{\mathrm{a}}\end{array}$ & $\begin{array}{l}\text { Property } \\
\text { category }^{\mathrm{b}}\end{array}$ \\
\hline Carbamazepine & Anti-epileptic drug & 16 & 2.8 & I \\
\hline Paracetamol & $\begin{array}{l}\text { Nonsteroidal } \\
\text { Anti-inflammatory drug }\end{array}$ & 0.4 & 1.2 & II \\
\hline Perfluorooctanoic acid & Surfactant & -4.2 & 1.6 & III \\
\hline Sulfamethoxazole & Antibiotic & 6.2 & 0.2 & III \\
\hline Triclosan & Antibiotic & 7.7 & 4.9 & I \\
\hline
\end{tabular}

${ }^{\mathrm{a}} \mathrm{p} K \mathrm{a}, \mathrm{pKb}$, and $\log D$ calculated with Chemaxon (http://www.chemicalize.com)

${ }^{\mathrm{b}}$ Properties Category I: neutral and moderate hydrophobic MPs $(\log D(\mathrm{pH} 7)>2)$; Category II: neutral hydrophilic MPs $(\log \mathrm{D}(\mathrm{pH} 7)<2)$; Category III: anionic MPs

coefficient $\left(K_{\mathrm{oc}}\right)$, and ionization state at the environmental $\mathrm{pH}$. In addition, they belong to different CoECs classes (Table 5).

CoECs with a property category I have the capability of passing through lipid bilayers of crop membranes due to their moderate hydrophobicity. Yet, they are still slightly water soluble and capable of traveling into cell fluids (Shenker et al. 2011). Property category III CoECs are characterized by weak interactions and sorption in soil. For example, the majority of sulfamethoxazole would be in the anionic species given a soil $\mathrm{pH}$ of 7 , with a smaller proportion remaining neutral. The anionic species would repel from soil particles and reside in the soil solution, whereas the neutral species would preferentially interact with organic carbon (Franklin et al. 2015).

\subsection{Risk Assessment}

There is only a risk if exposure occurs above an acceptable level. In the proposed regulation (European Commission 2018), a risk is defined as "the likelihood of identified hazards causing harm in a specified timeframe, including the severity of the consequences." In this chapter risks associated with SSI of STP effluent in regard to the ecosystem and humans are emphasized. Understanding these risks is crucial in allocating trade-offs in water supply, STP effluent reuse, and CoECs emission reduction.

A mixture made up of the organic compounds among the five highest reported concentrations in STP effluent represents a high risk quotient (RQ) of 120.70 (Table 6). RQs were calculated for each CoEC as predicted environmental concentration (PEC)/predicted no-effect concentration (PNEC). The PEC is based on a realistic worst-case scenario, with maximum reported concentrations in STP effluent (Cmax). Except for carbamazepine and perfluorooctanoic acid, all of the chemicals have RQs higher than 1, indicating a risk, paracetamol showing the highest RQ. Sulfamethoxazole is classified by the International Agency for Research and 
Table 6 Risk quotients of selected CoECs

\begin{tabular}{l|l|l|l}
\hline & Cmax in STP effluent (ng/l) & PNEC (ng/l) & RQ=PEC/PNEC \\
\hline Carbamazepine & $4,000^{\mathrm{a}}$ & $9,000^{\mathrm{b}}$ & 0.5 \\
\hline Paracetamol & $32,000^{\mathrm{c}}$ & $367^{\mathrm{d}}$ & 87 \\
\hline Perfluorooctanoic acid & $66^{\mathrm{e}}$ & $1.07^{\mathrm{e}}+06^{\mathrm{f}}$ & 0.00006 \\
\hline Sulfamethoxazole & $25,700^{\mathrm{g}}$ & $890^{\mathrm{h}}$ & 28.9 \\
\hline Triclosan & $11.3^{\mathrm{i}}$ & $2.6^{\mathrm{f}}$ & 4.3 \\
\hline Total & & 120.70 \\
\hline
\end{tabular}

Maximum concentration found in STP effluent $(C \max =\mathrm{PEC})$ retrieved from ${ }^{\mathrm{g}}$ Franklin et al. (2015), ${ }^{\mathrm{a} C h r i s t o u}$ et al. (2019a), ${ }^{\mathrm{c} P e r e i r a}$ et al. (2016), ${ }^{\mathrm{i}} \mathrm{Zheng}$ et al. (2020), ${ }^{\mathrm{e}} \mathrm{Man}$ et al. (2018). PNEC values obtained from ${ }^{\mathrm{b}}$ Zhao et al. (2017), ${ }^{\mathrm{d}}$ Riva et al. (2019), ${ }^{\mathrm{f}}$ Gredelj et al. (2018), ${ }^{\mathrm{h}}$ Huang et al. (2018)

Cancer (IARC) as possibly carcinogenic to humans (category 2B) (IARC 2016). The other compounds are not classified as to their carcinogenicity.

It should be noted that the RQ calculation does not take into account the filtration and purification function of the soil during SSI. Therefore, this RQ calculation may give an overestimation of the potential risks.

Typically, humans are exposed to a mixture of CoECs, which can give rise to mixture effects, i.e., they can elicit similar effects or exhibit the same mode of action. For mixtures of independently acting chemicals, the effects can be estimated directly from the probability of responses to the individual components (response addition) or the sum of biological responses (effects addition). Both concepts (independent action and dose/concentration addition) are based on the assumption that chemicals in a mixture do not influence each other's toxicity, i.e., they do not interact with each other at the biological target site (Blum et al. 2018; SCHER 2011). However, dose/ concentration addition can produce reliable estimates of combined effects, if the components share either a strictly identical molecular mechanism of action or belong to the group of so-called baseline toxicants (Boberg et al. 2019; SCHER 2011; Thomaidi et al. 2016). Yet, interactions may vary according to the relative dose levels, the routes, timing, and duration of exposure. Boberg et al. (2019) suggest a pragmatic step-by- step procedure for mixture risk assessment and propose tools for grouping of chemicals, whereby CoECs should be grouped for mixture risk assessment based on integrated in vivo and in vitro data, read-across as well as computational methods such as QSAR models or integrative systems biology.

Often the Threshold of Toxicological Concern (TTC) concept is used to provide an abbreviated risk assessment for the thousands of low molecular weight contaminants and other chemicals in food, provided that there is a sound intake estimate while specific toxicological data is lacking (Baken et al. 2018; Hollender et al. 2018; Riemenschneider et al. 2016). TTC is defined by examining the distribution of threshold values of the 5th percentile of non-observable effect level and the safety factor which is usually $100(=10 \times 10)$, reflecting species difference between rodents and humans (10-fold) and individual variations in humans (10-fold). The concept underlying this risk management approach is exactly the principle established by Paracelsus: any poison can be non-toxic if the dose is below the 
appropriate threshold and by WHO in numerous publications and all regulatory schemes of risk assessment in e.g. OECD countries. This principle cannot be applied to the regulation of genotoxic chemicals. Owing to their DNA interaction properties, genotoxic chemicals are not considered to have a safe threshold or dose (Baken et al. 2018; Bieber et al. 2018; Nohmi 2018).

\section{Conclusion}

Intentional reuse of sewage treatment plant (STP) effluent with sub-surface irrigation (SSI) can partly solve water scarcity issues. Consequently, an increased demand for STP effluent as freshwater source, rather than discharging it to the surface water, may lead to the installation and optimization of treatment facilities to produce effluent of a desired quality for irrigation purposes. Worldwide, guidelines related to contaminants of emerging concern (CoECs) and water reuse have only been adopted by a few states in the United states. California produced specific national mandatory regulations related to CoECs. At European level, the current proposed regulation for STP effluent reuse lacks minimum requirements for CoECs. Enhancing the water policy framework with STP effluent reuse may promote well-planned water reuse programs, which will require consistent risk-based standards for different types of agricultural irrigation systems.

The quality of the irrigation water that reaches the crop and the risk associated with STP effluent is highly dependent on the method of supply. SSI provides a (saturated) soil barrier, surpassing drip and sprinkler irrigation where the STP effluent comes in direct contact with the crops. On the contrary, SSI directly introduces STP effluent into groundwater which may lead to deep groundwater seepage.

Not many studies are available with regard to the fate and risks for a broad list of CoECs in SSI systems. Indeed, studies done in river bank filtration, managed aquifer recharge, and constructed wetlands have proven that the soil may have the ability to act as a filter and buffer zone. These systems are similar in terms of their anaerobic medium; it can therefore be expected that biotransformation processes which are key removal processes in these systems will also be dominant in SSI. On the other hand, these systems were constructed for purification functions, while SSI also serves as an irrigation system which may have shorter residence times with regard to crop uptake and longer residence times for groundwater seepage. This objective of SSI is the basis for the difference in design and operational conditions compared to the other systems. Therefore, the mechanisms of biotransformation processes for a broad list of CoECs are still unknown. In addition the interplay between aerobic and anaerobic conditions of SSI remains not yet fully understood. Furthermore, the balance between irrigation supply with STP effluent and the minimum stream flow needed for ecosystem functioning should be conserved. As a consequence, to explore the full potential, i.e., risk and opportunities, of STP effluent reuse in SSI, the following topics should be addressed in profound studies: 
- Identification of a broad list of CoECs and their transformation products in groundwater, soil, and crops of SSI systems for several years before, during, and after the growing season. The conditions of SSI system will primarily be anaerobic, but sub-oxic conditions are not excluded. These fate studies may additionally pinpoint how and to what degree SSI with STP effluent can contribute to reduced CoECs emission to surface water compared with current direct discharge.

- Anaerobic biotransformation mechanism in SSI and the interplay with aerobic conditions in the rhizosphere. From the constructed wetlands and river bank filtration studies assessed in this review, it can be expected that biotransformation may be the most dominant removal process present in SSI. Especially the residence time distribution during the year can highly influence the effect of biotransformation due to among others microbiological adaptation.

- Adequate risk assessment which results in classifying trade-offs in water supply, STP effluent reuse, and CoECs emission reduction. These trade-offs determine critical factors in upscaling SSI to larger scales.

\section{Summary}

Worldwide, fresh water scarcity is often caused by a high demand from the agricultural sector that globally accounts for $69 \%$ of fresh water withdrawal. This is not only an issue for arid regions with low rainfall and high population density that are prone to increasing water stress; temperate areas with intense agriculture also suffer from frequent non-potable water shortages. The intentional reuse of sewage treatment plant (STP) effluent in sub-surface irrigation (SSI), which is currently discharged in large volumes to surface water, may provide an alternative freshwater source. Additionally, the load of contaminants of emerging concern (CoECs) to surface water may be reduced due to soil passage and related (bio)transformation processes. In this review, the policies and guidelines concerning non-potable water reuse are highlighted. We discuss the processes that affect the fate of CoECs in SSI, and the expectations with regard to exposure and risks. Furthermore, knowledge gaps as well as challenges and opportunities of intentional STP effluent reuse via SSI are addressed with the aim of stimulating future research toward an enhanced understanding of the fate and risks of CoECs in SSI.

Acknowledgments This work is part of the research program "Re-USe of Treated effluent for agriculture (RUST)" with project number ALWGK.2016.016, which is financed by the Netherlands Organization for Scientific Research (NWO), KWR Water Research Institute, and $\mathrm{KnowH}_{2} \mathrm{O}$.

The authors declare that they have no conflict of interest. 


\section{References}

Adrion AC, Nakamura J, Shea D, Aitken MD (2016) Screening nonionic surfactants for enhanced biodegradation of polycyclic aromatic hydrocarbons remaining in soil after conventional biological treatment. Environ Sci Technol 50:3838-3845. https://doi.org/10.1021/acs.est.5b05243

Albergamo V, Blankert B, Cornelissen ER, Hofs B, Knibbe WJ, van der Meer W, de Voogt P (2019) Removal of polar organic micropollutants by pilot-scale reverse osmosis drinking water treatment. Water Res 148:535-545. https://doi.org/10.1016/j.watres.2018.09.029

Arden S, Ma X (2018) Constructed wetlands for greywater recycle and reuse: a review. Sci Total Environ 630:587-599. https://doi.org/10.1016/j.scitotenv.2018.02.218

Arp HPH, Brown TN, Berger U, Hale SE (2017) Ranking REACH registered neutral, ionizable and ionic organic chemicals based on their aquatic persistency and mobility. Environ Sci Process Impacts 19:939-955. https://doi.org/10.1039/c7em00158d

Australian Government Initiative (2006) Australian guidelines for water recycling [WWW Document]. http://www.waterquality.gov.au/guidelines/recycled-water. Accessed 26 Apr 2019

Ayars JE, Christen EW, Hornbuckle JW (2006) Controlled drainage for improved water management in arid regions irrigated agriculture. Agric Water Manag 86:128-139. https://doi.org/10. 1016/j.agwat.2006.07.004

Ayars JE, Fulton A, Taylor B (2015) Subsurface drip irrigation in California-here to stay? Agric Water Manag 157:39-47. https://doi.org/10.1016/j.agwat.2015.01.001

Baken KA, Sjerps RMA, Schriks M, van Wezel AP (2018) Toxicological risk assessment and prioritization of drinking water relevant contaminants of emerging concern. Environ Int 118:293-303. https://doi.org/10.1016/j.envint.2018.05.006

Beard JE, Bierkens MFP, Bartholomeus RP (2019) Following the water: characterising de facto wastewater reuse in agriculture in the Netherlands. Sustain 11:1-20. https://doi.org/10.3390/ su11215936

Benard P, Kroener E, Vontobel P, Kaestner A, Carminati A (2016) Advances in water resources water percolation through the root-soil interface. Adv Water Resour 95:190-198. https://doi. org/10.1016/j.advwatres.2015.09.014

Beneduce L, Gatta G, Bevilacqua A, Libutti A, Tarantino E, Bellucci M, Troiano E, Spano G (2017) Impact of the reusing of food manufacturing wastewater for irrigation in a closed system on the microbiological quality of the food crops. Int J Food Microbiol 260:51-58. https://doi.org/10. 1016/j.ijfoodmicro.2017.08.009

Bertelkamp C, Reungoat J, Cornelissen ER, Singhal N, Reynisson J, Cabo AJ, van der Hoek JP, Verliefde ARD (2014) Sorption and biodegradation of organic micropollutants during river bank filtration: a laboratory column study. Water Res 52:231-241. https://doi.org/10.1016/j. watres.2013.10.068

Bertelkamp C, Verliefde ARD, Schoutteten K, Vanhaecke L, Vanden Bussche J, Singhal N, van der Hoek JP (2016) The effect of redox conditions and adaptation time on organic micropollutant removal during river bank filtration: a laboratory-scale column study. Sci Total Environ 544:309-318. https://doi.org/10.1016/j.scitotenv.2015.11.035

Bezza FA, Chirwa EMN (2017) The role of lipopeptide biosurfactant on microbial remediation of aged polycyclic aromatic hydrocarbons (PAHs)-contaminated soil. Chem Eng J 309:563-576. https://doi.org/10.1016/j.cej.2016.10.055

Bieber S, Snyder SA, Dagnino S, Rauch-Williams T, Drewes JE (2018) Management strategies for trace organic chemicals in water - a review of international approaches. Chemosphere 195:410-426. https://doi.org/10.1016/j.chemosphere.2017.12.100

Bijl DL, Biemans H, Bogaart PW, Dekker SC, Doelman JC, Stehfest E, van Vuuren DP (2018) A global analysis of future water deficit based on different allocation mechanisms. Water Resour Res 54:5803-5824. https://doi.org/10.1029/2017WR021688

Bilal M, Adeel M, Rasheed T, Zhao Y, Iqbal HMN (2019) Emerging contaminants of high concern and their enzyme-assisted biodegradation - a review. Environ Int 124:336-353. https://doi.org/ 10.1016/j.envint.2019.01.011 
Blum KM, Andersson PL, Ahrens L, Wiberg K, Haglund P (2018) Persistence, mobility and bioavailability of emerging organic contaminants discharged from sewage treatment plants. Sci Total Environ 612:1532-1542. https://doi.org/10.1016/j.scitotenv.2017.09.006

Boberg J, Dybdahl M, Petersen A, Hass U, Svingen T, Vinggaard AM (2019) A pragmatic approach for human risk assessment of chemical mixtures. Curr Opin Toxicol 15:1-7. https:// doi.org/10.1016/j.cotox.2018.11.004

Bonaiti G, Borin M (2010) Efficiency of controlled drainage and subirrigation in reducing nitrogen losses from agricultural fields. Agric Water Manag 98:343-352. https://doi.org/10.1016/j. agwat.2010.09.008

Brunner A, Kolkman A, Hofman-Caris R, Bertelkamp C, Siegers W, Vughs D, ter Laak T (2018) BTO report transformation products in the water (BTO 2018.017 I February 2018)

Brunner AM, Vughs D, Siegers W, Bertelkamp C, Hofman-Caris R, Kolkman A, ter Laak T (2019) Monitoring transformation product formation in the drinking water treatments rapid sand filtration and ozonation. Chemosphere 214:801-811. https://doi.org/10.1016/j.chemosphere. 2018.09.140

Brunsch AF, ter Laak TL, Christoffels E, Rijnaarts HHM, Langenhoff AAM (2018) Retention soil filter as post-treatment step to remove micropollutants from sewage treatment plant effluent. Sci Total Environ 637-638:1098-1107. https://doi.org/10.1016/j.scitotenv.2018.05.063

California Department of Public Health (CDPH) (2018) Regulations related to recycled water. Title 22 code of regulations. Californa Waterboards. Draft amendment to the recycled water policy

California Water Boards (2019) Laws and regulations [WWW Document]. https://www. waterboards.ca.gov/laws_regulations/. Accessed 1 Apr 2019

Campa MF, Techtmann SM, Gibson CM, Zhu X, Patterson M, Garcia De Matos Amaral A, Ulrich N, Campagna SR, Grant CJ, Lamendella R, Hazen TC (2018) Impacts of glutaraldehyde on microbial community structure and degradation potential in streams impacted by hydraulic fracturing. Environ Sci Technol 52:5989-5999. https://doi.org/10.1021/acs.est.8b00239

Ccanccapa A, Masiá A, Andreu V, Picó Y (2016) Spatio-temporal patterns of pesticide residues in the Turia and Júcar Rivers (Spain). Sci Total Environ 540:200-210. https://doi.org/10.1016/j. scitotenv.2015.06.063

Chen B, Han MY, Peng K, Zhou SL, Shao L, Wu XF, Wei WD, Liu SY, Li Z, Li JS, Chen GQ (2018) Global land-water nexus: agricultural land and freshwater use embodied in worldwide supply chains. Sci Total Environ 613-614:931-943. https://doi.org/10.1016/j.scitotenv.2017. 09.138

Christou A, Agüera A, Bayona JM, Cytryn E, Fotopoulos V, Lambropoulou D, Manaia CM, Michael C, Revitt M, Schröder P, Fatta-Kassinos D (2017a) The potential implications of reclaimed wastewater reuse for irrigation on the agricultural environment: the knowns and unknowns of the fate of antibiotics and antibiotic resistant bacteria and resistance genes - a review. Water Res 123:448-467. https://doi.org/10.1016/j.watres.2017.07.004

Christou A, Karaolia P, Hapeshi E, Michael C, Fatta-Kassinos D (2017b) Corrigendum to: "Longterm wastewater irrigation of vegetables in real agricultural systems: Concentration of pharmaceuticals in soil, uptake and bioaccumulation in tomato fruits and human health risk assessment." [Water Res. 109 (2017) 24-34] (S004313541). Water Res. 119:312. https://doi.org/10. 1016/j.watres.2017.04.065

Christou A, Kyriacou MC, Georgiadou EC, Papamarkou R, Hapeshi E, Karaolia P, Michael C, Fotopoulos V, Fatta-Kassinos D (2019a) Uptake and bioaccumulation of three widely prescribed pharmaceutically active compounds in tomato fruits and mediated effects on fruit quality attributes. Sci Total Environ 647:1169-1178. https://doi.org/10.1016/j.scitotenv.2018.08.053

Christou A, Papadavid G, Dalias P, Fotopoulos V, Michael C, Bayona JM, Piña B, Fatta-Kassinos D (2019b) Ranking of crop plants according to their potential to uptake and accumulate contaminants of emerging concern. Environ Res 170:422-432. https://doi.org/10.1016/j. envres.2018.12.048 
Cipullo S, Prpich G, Campo P, Coulon F (2018) Assessing bioavailability of complex chemical mixtures in contaminated soils: progress made and research needs. Sci Total Environ 615:708-723. https://doi.org/10.1016/j.scitotenv.2017.09.321

Council of the European Communities (1991) Directive concerning the protection of waters against pollution caused by nitrates from agricultural sources (91/676/EEC). Off J Eur Communities

Council of the European Communities (2000) Water Framework Directive (2000/60/EC). Off J Eur Communities 1. https://doi.org/10.1039/ap9842100196

Cycoń M, Mrozik A, Piotrowska-Seget Z (2019) Antibiotics in the soil environment - degradation and their impact on microbial activity and diversity. Front Microbiol 10. https://doi.org/10.3389/ fmicb.2019.00338

Delli Compagni R, Gabrielli M, Polesel F, Turolla A, Trapp S, Vezzaro L, Antonelli M (2020) Risk assessment of contaminants of emerging concern in the context of wastewater reuse for irrigation: an integrated modelling approach. Chemosphere 242:125185. https://doi.org/10. 1016/j.chemosphere.2019.125185

Doucette WJ, Shunthirasingham C, Dettenmaier EM, Zaleski RT, Fantke P, Arnot JA (2018) A review of measured bioaccumulation data on terrestrial plants for organic chemicals: metrics, variability, and the need for standardized measurement protocols. Environ Toxicol Chem 37:21-33. https://doi.org/10.1002/etc.3992

Drewes JE, Uwe H, Zhitenev Veronikaa SK (2017) Characterization of unplanned water reuse in the EU final report:64. https://doi.org/10.2779/597701

Dulio V, van Bavel B, Brorström-Lundén E, Harmsen J, Hollender J, Schlabach M, Slobodnik J, Thomas K, Koschorreck J (2018) Emerging pollutants in the EU: 10 years of NORMAN in support of environmental policies and regulations. Environ Sci Eur 30. https://doi.org/10.1186/ s12302-018-0135-3

ECHA (2017) Guidance on information requirements and chemical safety assessment - part E: risk characterisation. Eur Chem Agency:1-58. https://doi.org/10.2823/139408

EEC Council (1991) 91/271/EEC of 21 May 1991 concerning urban waste-water treatment. EEC Counc Dir 10. https://doi.org/http://eur-lex.europa.eu/legal-content/en/ALL/? uri=CELEX:31991L0271

EurEau (2018) EurEau position on the regulation on minimum requirements for water reuse. 32:1-7

European Comission (2008) Directive 2008/105/EC of the European Parliament and of the Council of 16 December 2008 on environmental quality standards in the field of water policy. Off J Eur Union:L348/84-L348/97. https://doi.org/http://eur-lex.europa.eu/legal-content/EN/TXT/? uri=celex:32008L0105

European Commission (2004) Regulation (EC) No 852/2004 of the European Parliament and of the Council of 29 April 2004 on the hygiene of foodstuffs. Off J Eur Communities 2002:1-54. https://doi.org/http://eur-lex.europa.eu/pri/en/oj/dat/2003/1_285/1_28520031101en00330037. pdf

European Commission (2005) Regulation (EC) No. 2073/2005 of The European Parliament and of The Council of 15 November 2005 on microbiological criteria for foodstuffs. Off J Eur Union

European Commission (2006) Commission regulation (EC) No 1881/2006 of 19 December 2006 setting maximum levels for certain contaminants in foodstuffs. Off J Eur Union 2006:5-24

European Commission (2011) Commission Regulation (EU) No 142/2011 of 25 February 2011 implementing Regulation (EC) No 1069/2009 of the European Parliament and of the Council laying down health rules as regards animal by-products and derived products not intended for human consumption. Off J Eur Union

European Commission (2014) Directive of 20 June 2014 amending Annex II to Directive 2006/118/ EC of the European Parliament and of the Council on the protection of groundwater against pollution and deterioration (2014/80/EU) 2014, 4

European Commission (2018) Proposal for a REGULATION OF THE EUROPEAN PARLIAMENT AND OF THE COUNCIL on minimum requirements for water reuse 
European Parliament and the Council of the European Union (2005) Regulation (EC) No 183/2005 of the European Parliament and of the Council of 12 January 2005 laying down requirements for feed hygiene. Off J Eur Union 2004

European Parliament and the Council (2005) Regulation (EC) No 396/2005 of the European Parliament and of the Council of 23 February 2005 on maximum residue levels of pesticides in or on food and feed of plant and animal origin and amending Council Directive 91/414/EEC. Off J Eur Union

Europian Commission (2012) Blueprint to Safeguard Europe's Water Resources.

Faour-Klingbeil D, Todd ECD (2018) The impact of climate change on raw and untreated wastewater use for agriculture, especially in arid regions: a review. Foodborne Pathog Dis 15:61-72. https://doi.org/10.1089/fpd.2017.2389

Fekadu S, Alemayehu E, Dewil R, Van der Bruggen B (2019) Pharmaceuticals in freshwater aquatic environments: a comparison of the African and European challenge. Sci Total Environ 654:324-337. https://doi.org/10.1016/j.scitotenv.2018.11.072

Food and Argriculture Organization of the United Nations (2016) Theme: water uses [WWW Document]. http://www.fao.org/nr/water/aquastat/water_use/index.stm. Accessed 14 Apr 2018

Franklin AM, Williams CF, Andrews DM, Woodward EE, Watson JE (2015) Uptake of three antibiotics and an antiepileptic drug by wheat crops spray irrigated with wastewater treatment plant effluent. J Environ Qual 45:546. https://doi.org/10.2134/jeq2015.05.0257

Fraz S, Lee AH, Pollard S, Srinivasan K, Vermani A, Wilson JY (2019) Parental gemfibrozil exposure impacts zebrafish F1 offspring, but not subsequent generations. Aquat Toxicol 212:194-204. https://doi.org/10.1016/j.aquatox.2019.04.020

Gago-Ferrero P, Krettek A, Fischer S, Wiberg K, Ahrens L (2018) Suspect screening and regulatory databases: a powerful combination to identify emerging micropollutants. Environ Sci Technol 52:6881-6894. https://doi.org/10.1021/acs.est.7b06598

Garcia-Cuerva L, Berglund EZ, Binder AR (2016) Public perceptions of water shortages, conservation behaviors, and support for water reuse in the U.S. Resour Conserv Recycl 113:106-115. https://doi.org/10.1016/j.resconrec.2016.06.006

García-Santiago X, Garrido JM, Lema JM, Franco-Uría A (2017) Fate of pharmaceuticals in soil after application of STPs products: influence of physicochemical properties and modelling approach. Chemosphere 182:406-415. https://doi.org/10.1016/j.chemosphere.2017.05.049

Ghattas AK, Fischer F, Wick A, Ternes TA (2017) Anaerobic biodegradation of (emerging) organic contaminants in the aquatic environment. Water Res 116:268-295. https://doi.org/10.1016/j. watres.2017.02.001

Gillefalk M, Massmann G, Nützmann G, Hilt S (2018) Potential impacts of induced bank filtration on surface water quality: a conceptual framework for future research. Water (Switzerland):10. https://doi.org/10.3390/w10091240

Goldstein M, Shenker M, Chefetz B (2014) Insights into the uptake processes of wastewater-borne pharmaceuticals by vegetables. Environ Sci Technol 48:5593-5600. https://doi.org/10.1021/ es5008615

Gonzales-Gustavson E, Rusiñol M, Medema G, Calvo M, Girones R (2019) Quantitative risk assessment of norovirus and adenovirus for the use of reclaimed water to irrigate lettuce in Catalonia. Water Res 153:91-99. https://doi.org/10.1016/j.watres.2018.12.070

Gorito AM, Ribeiro AR, Almeida CMR, Silva AMT (2017) A review on the application of constructed wetlands for the removal of priority substances and contaminants of emerging concern listed in recently launched EU legislation. Environ Pollut 227:428-443. https://doi. org/10.1016/j.envpol.2017.04.060

Gredelj A, Barausse A, Grechi L, Palmeri L (2018) Deriving predicted no-effect concentrations (PNECs) for emerging contaminants in the river Po, Italy, using three approaches: assessment factor, species sensitivity distribution and AQUATOX ecosystem modelling. Environ Int 119:66-78. https://doi.org/10.1016/j.envint.2018.06.017 
Greskowiak J, Hamann E, Burke V, Massmann G (2017) The uncertainty of biodegradation rate constants of emerging organic compounds in soil and groundwater - a compilation of literature values for 82 substances. Water Res 126:122-133. https://doi.org/10.1016/j.watres.2017.09.017

Grill G, Khan U, Lehner B, Nicell J, Ariwi J (2016) Risk assessment of down-the-drain chemicals at large spatial scales: model development and application to contaminants originating from urban areas in the Saint Lawrence River Basin. Sci Total Environ 541:825-838. https://doi.org/10. 1016/j.scitotenv.2015.09.100

Gude VG (2017) Desalination and water reuse to address global water scarcity. Rev Environ Sci Biotechnol 16:591-609. https://doi.org/10.1007/s11157-017-9449-7

Gunarathna MHJP, Sakai K, Nakandakari T, Kazuro M, Onodera T, Kaneshiro H, Uehara H, Wakasugi K (2017) Optimized subsurface irrigation system (OPSIS): beyond traditional subsurface irrigation. Water (Switzerland) 9. https://doi.org/10.3390/w9080599

Gupta D, Madramootoo CA (2017) Fate and transport of Escherichia coli in tomato production. Expo Heal 9:13-25. https://doi.org/10.1007/s12403-016-0217-7

Halden RU (2015) Epistemology of contaminants of emerging concern and literature meta-analysis. J Hazard Mater 282:2-9. https://doi.org/10.1016/j.jhazmat.2014.08.074

Hamann E, Stuyfzand PJ, Greskowiak J, Timmer H, Massmann G (2016) The fate of organic micropollutants during long-term/long-distance river bank filtration. Sci Total Environ 545-546:629-640. https://doi.org/10.1016/j.scitotenv.2015.12.057

Hollender J, Schymanski EL, Singer H, Ferguson PL (2017) Non-target screening with high resolution mass spectrometry in the environment: ready to go? Environ Sci Technol. https:// doi.org/10.1021/acs.est.7b02184

Hollender J, Rothardt J, Radny D, Loos M, Epting J, Huggenberger P, Borer P, Singer H (2018) Comprehensive micropollutant screening using LC-HRMS/MS at three riverbank filtration sites to assess natural attenuation and potential implications for human health. Water Res $\mathrm{X}$ 1:100007. https://doi.org/10.1016/j.wroa.2018.100007

Hong PY, Julian TR, Pype ML, Jiang SC, Nelson KL, Graham D, Pruden A, Manaia CM (2018) Reusing treated wastewater: consideration of the safety aspects associated with antibioticresistant bacteria and antibiotic resistance genes. Water (Switzerland):10. https://doi.org/10. 3390/w10030244

Huang Q, Bu Q, Zhong W, Shi K, Cao Z, Yu G (2018) Derivation of aquatic predicted no-effect concentration (PNEC) for ibuprofen and sulfamethoxazole based on various toxicity endpoints and the associated risks. Chemosphere 193:223-229. https://doi.org/10.1016/j.chemosphere. 2017.11.029

International Agency for Research and Cancer (2016) Some chemicals used as solvents and in polymer manufacture, IARC Monographs on the Evaluation of Carcinogenic Risks to Humans

International Organization for Standardization (2015) Guidelines for treated wastewater use for irrigation projects [WWW Document]. ISO 16075. https://www.iso.org/standard/62756.html

IWA (2018) The reuse opportunity. Atmos Chem Phys Discuss 1-26. https://doi.org/10.5194/acp2016-176

Jaime N, Peta N, Tobias H, Stefanie K, Maria K, Roland M, Thorsten R, Rita S, Beate E (2018) Application of cell-based bioassays to evaluate treatment efficacy of conventional and intensified treatment wetlands. Environ Sci Water Res Technol 4(2):206-217. https://doi.org/10.1016/ j.watres.2017.09.004

Jaramillo MF, Restrepo I (2017) Wastewater reuse in agriculture: a review about its limitations and benefits. Sustain 9. https://doi.org/10.3390/su9101734

Jin J, Sun K, Wang Z, Han L, Pan Z, Wu F, Liu X, Zhao Y, Xing B (2015) Characterization and phthalate esters sorption of organic matter fractions isolated from soils and sediments. Environ Pollut 206:24-31. https://doi.org/10.1016/j.envpol.2015.06.031

Joint Research Centre (2017) Minimum quality requirements for water reuse in agricultural irrigation and aquifer recharge - towards a water reuse regulatory instrument at EU level. https://doi.org/10.2760/887727 
Kahl S, Nivala J, van Afferden M, Müller RA, Reemtsma T (2017) Effect of design and operational conditions on the performance of subsurface flow treatment wetlands: emerging organic contaminants as indicators. Water Res 125:490-500. https://doi.org/10.1016/j.watres.2017.09.004

Kase R, Javurkova B, Simon E, Swart K, Buchinger S, Könemann S, Escher BI, Carere M, Dulio V, Ait-Aissa S, Hollert H, Valsecchi S, Polesello S, Behnisch P, di Paolo C, Olbrich D, Sychrova E, Gundlach M, Schlichting R, Leborgne L, Clara M, Scheffknecht C, Marneffe Y, Chalon C, Tusil P, Soldan P, von Danwitz B, Schwaiger J, Morán A, Bersani F, Perceval O, Kienle C, Vermeirssen E, Hilscherova K, Reifferscheid G, Werner I (2018) Screening and risk management solutions for steroidal estrogens in surface and wastewater. Trends Anal Chem 102:343-358. https://doi.org/10.1016/j.trac.2018.02.013

Khalid S, Shahid M, Natasha IB, Sarwar T, Shah AH, Niazi NK (2018) A review of environmental contamination and health risk assessment of wastewater use for crop irrigation with a focus on low and high-income countries. Int J Environ Res Public Health 15:1-36. https://doi.org/10. 3390/ijerph15050895

Kibuye FA, Gall HE, Elkin KR, Ayers B, Veith TL, Miller M, Jacob S, Hayden KR, Watson JE, Elliott HA (2019) Fate of pharmaceuticals in a spray-irrigation system: from wastewater to groundwater. Sci Total Environ 654:197-208. https://doi.org/10.1016/j.scitotenv.2018.10.442

Klaassen C (2008) Toxicology: the basic science of poison. McGraw-Hill, New York. ISBN 978-1259-86374-5

Lamichhane S, Bal Krishna KC, Sarukkalige R (2016) Polycyclic aromatic hydrocarbons (PAHs) removal by sorption: a review. Chemosphere 148:336-353. https://doi.org/10.1016/j. chemosphere.2016.01.036

Larsson DGJ, Andremont A, Bengtsson-Palme J, Brandt KK, de Roda Husman AM, Fagerstedt P, Fick J, Flach C-F, Gaze WH, Kuroda M, Kvint K, Laxminarayan R, Manaia CM, Nielsen KM, Plant L, Ploy M-C, Segovia C, Simonet P, Smalla K, Snape J, Topp E, van Hengel AJ, VernerJeffreys DW, Virta MPJ, Wellington EM, Wernersson A-S (2018) Critical knowledge gaps and research needs related to the environmental dimensions of antibiotic resistance. Environ Int 117:132-138. https://doi.org/10.1016/j.envint.2018.04.041

Legislative Counsel Bureau (2018) Senate Bill No. 966 1-4

Li Y, Zhu G, Ng WJ, Tan SK (2014) A review on removing pharmaceutical contaminants from wastewater by constructed wetlands: design, performance and mechanism. Sci Total Environ 468-469:908-932. https://doi.org/10.1016/j.scitotenv.2013.09.018

Luo Y, Guo W, Hao H, Duc L, Ibney F, Zhang J, Liang S, Wang XC (2014) Science of the total environment a review on the occurrence of micropollutants in the aquatic environment and their fate and removal during wastewater treatment. Sci Total Environ 473-474:619-641. https://doi. org/10.1016/j.scitotenv.2013.12.065

Magdeburg A, Stalter D, Schlu M, Ternes T (2014) ScienceDirect evaluating the efficiency of advanced wastewater treatment: target analysis of organic contaminants and (geno- ) toxicity assessment tell a different 0 . https://doi.org/10.1016/j.watres.2013.11.041

Man YB, Chow KL, Tsang YF, Lau FTK, Fung WC, Wong MH (2018) Fate of bisphenol A, perfluorooctanoic acid and perfluorooctanesulfonate in two different types of sewage treatment works in Hong Kong. Chemosphere 190:358-367. https://doi.org/10.1016/j.chemosphere.2017. 10.001

Manaia CM (2017) Assessing the risk of antibiotic resistance transmission from the environment to humans: non-direct proportionality between abundance and risk. Trends Microbiol 25:173-181. https://doi.org/10.1016/j.tim.2016.11.014

Mao J, Nierop KGJ, Dekker SC, Dekker LW, Chen B (2019) Understanding the mechanisms of soil water repellency from nanoscale to ecosystem scale: a review. J Soil Sediment 19:171-185. https://doi.org/10.1007/s11368-018-2195-9

Martínez J, Reca J (2014) Water use efficiency of surface drip irrigation versus an alternative subsurface drip irrigation method. J Irrig Drain Eng 140:04014030. https://doi.org/10.1061/ (asce)ir.1943-4774.0000745

Massoud MA, Kazarian A, Alameddine I, Al-Hindi M (2018) Factors influencing the reuse of reclaimed water as a management option to augment water supplies. Environ Monit Assess 190. https://doi.org/10.1007/s10661-018-6905-y 
Miller EL, Nason SL, Karthikeyan KG, Pedersen JA (2016) Root uptake of pharmaceuticals and personal care product ingredients. Environ Sci Technol 50:525-541. https://doi.org/10.1021/ acs.est.5b01546

Mukherjee B, Adhikary S (2019) Chapter-3 water efficient rice cultivation: technological interventions, Water efficient rice cultivation: technological interventions. https://doi.org/10.22271/ed. book.386

Munz NA, Burdon FJ, de Zwart D, Junghans M, Melo L, Reyes M, Schönenberger U, Singer HP, Spycher B, Hollender J, Stamm C (2016) Pesticides drive risk of micropollutants in wastewaterimpacted streams during low flow conditions. Water Res 110:366-377. https://doi.org/10.1016/ j.watres.2016.11.001

Ncube S, Madikizela LM, Chimuka L, Nindi MM (2018) Environmental fate and ecotoxicological effects of antiretrovirals: a current global status and future perspectives. Water Res 145:231-247. https://doi.org/10.1016/j.watres.2018.08.017

Nguyen T, Westerhoff P, Furlong E, Kolpin DW, Batt AL, Mash HE, Schenck KM, Scott Boone J, Jacelyn R, Glassmeyer ST (2018) Peer reviewed modeled de facto reuse and contaminants of emerging concern in drinking water source. J Am Water Works Assoc 110(4):E2-E18. https:// doi.org/10.1002/awwa.1052

Nham HTT, Greskowiak J, Nödler K, Rahman MA, Spachos T, Rusteberg B, Massmann G, Sauter M, Licha T (2015) Modeling the transport behavior of 16 emerging organic contaminants during soil aquifer treatment. Sci Total Environ 514:450-458. https://doi.org/10.1016/j. scitotenv.2015.01.096

Nohmi T (2018) Thresholds of genotoxic and non-genotoxic carcinogens. Toxicol Res 34:281-290. https://doi.org/10.5487/TR.2018.34.4.281

NORMAN (2019) NORMAN Suspect List Exchange [WWW Document]. https://www.normannetwork.com/?q=suspect-list-exchange

Otto S, Banitz T, Thullner M, Harms H, Wick LY (2016) Effects of facilitated bacterial dispersal on the degradation and emission of a desorbing contaminant. Environ Sci Technol 50:6320-6326. https://doi.org/10.1021/acs.est.6b00567

Pan M, Wong CKC, Chu LM (2014) Distribution of antibiotics in wastewater-irrigated soils and their accumulation in vegetable crops in the Pearl River Delta, Southern China. J Agric Food Chem 62:11062-11069. https://doi.org/10.1021/jf503850v

Pan Z, Song C, Li L, Wang H, Pan Y, Wang C, Li J, Wang T, Feng X (2019) Membrane technology coupled with electrochemical advanced oxidation processes for organic wastewater treatment: recent advances and future prospects. Chem Eng J 1-19. https://doi.org/10.1016/j.cej.2019.01. 188

Park J, Cho KH, Lee E, Lee S, Cho J (2018) Sorption of pharmaceuticals to soil organic matter in a constructed wetland by electrostatic interaction. Sci Total Environ 635:1345-1350. https://doi. org/10.1016/j.scitotenv.2018.04.212

Peng L, Zhang XT, Yin J, Xu SY, Zhang Y, Xie DT, Li ZL (2016) Geobacter sulfurreducens adapts to low electrode potential for extracellular electron transfer. Electrochim Acta 191:743-749. https://doi.org/10.1016/j.electacta.2016.01.033

Pepper IL, Gerba CP (2018) Risk of infection from Legionella associated with spray irrigation of reclaimed water. Water Res 139:101-107. https://doi.org/10.1016/j.watres.2018.04.001

Pereira AMPT, Silva LJG, Lino CM, Meisel LM, Pena A (2016) Assessing environmental risk of pharmaceuticals in Portugal: an approach for the selection of the Portuguese monitoring stations in line with Directive 2013/39/EU. Chemosphere 144:2507-2515. https://doi.org/10.1016/j. chemosphere.2015.10.100

Petrie B, Barden R, Kasprzyk-Hordern B (2015) A review on emerging contaminants in wastewaters and the environment: current knowledge, understudied areas and recommendations for future monitoring. Water Res 72:3-27. https://doi.org/10.1016/j.watres.2014.08.053

Petrie B, Rood S, Smith BD, Proctor K, Youdan J, Barden R, Kasprzyk-Hordern B (2018) Biotic phase micropollutant distribution in horizontal sub-surface flow constructed wetlands. Sci Total Environ 630:648-657. https://doi.org/10.1016/j.scitotenv.2018.02.242

Picó Y, Alvarez-Ruiz R, Alfarhan AH, El-Sheikh MA, Alobaid SM, Barceló D (2019) Uptake and accumulation of emerging contaminants in soil and plant treated with wastewater under real- 
world environmental conditions in the Al Hayer area (Saudi Arabia). Sci Total Environ 652:562-572. https://doi.org/10.1016/j.scitotenv.2018.10.224

Poff NLR (2018) Beyond the natural flow regime? Broadening the hydro-ecological foundation to meet environmental flows challenges in a non-stationary world. Freshw Biol 63:1011-1021. https://doi.org/10.1111/fwb.13038

Poursat BAJ, Van Spanning RJM, de Voogt P, Parsons J (2019) Implications of microbial adaptation for the assessment of environmental persistence of chemicals. Crit Rev Environ Sci Technol. https://doi.org/10.1080/10643389.2019.1607687

Price J, Fielding KS, Gardner J, Leviston Z, Green M (2015) Developing effective messages about potable recycled water: the importance of message structure and content. Water Resour Res 51:2174-2187. https://doi.org/10.1002/2014WR016514

Quesada HB, Baptista ATA, Cusioli LF, Seibert D, de Oliveira Bezerra C, Bergamasco R (2019) Surface water pollution by pharmaceuticals and an alternative of removal by low-cost adsorbents: a review. Chemosphere 222:766-780. https://doi.org/10.1016/j.chemosphere.2019.02. 009

Reemtsma T, Berger U, Arp HPH, Gallard H, Knepper TP, Neumann M, Quintana JB, De Voogt P (2016) Mind the gap: persistent and mobile organic compounds - water contaminants that slip through. Environ Sci Technol 50:10308-10315. https://doi.org/10.1021/acs.est.6b03338

Reid T, Droppo IG, Weisener CG (2020) Tracking functional bacterial biomarkers in response to a gradient of contaminant exposure within a river continuum. Water Res 168:115167. https://doi. org/10.1016/j.watres.2019.115167

Ren X, Zeng G, Tang L, Wang J, Wan J, Liu Y, Yu J, Yi H, Ye S, Deng R (2018) Sorption, transport and biodegradation - an insight into bioavailability of persistent organic pollutants in soil. Sci Total Environ 610-611:1154-1163. https://doi.org/10.1016/j.scitotenv.2017.08.089

Rengasamy P (2018) Irrigation water quality and soil structural stability: a perspective with some new insights. Agronomy 8:72. https://doi.org/10.3390/agronomy8050072

Ricart S, Rico AM, Ribas A (2019) Risk-yuck factor nexus in reclaimed wastewater for irrigation: comparing farmers' attitudes and public perception. Water (Switzerland):11. https://doi.org/10. 3390/w11020187

Rice J, Wutich A, White DD, Westerhoff P (2016) Comparing actual de facto wastewater reuse and its public acceptability: a three city case study. Sustain Cities Soc 27:467-474. https://doi.org/ 10.1016/j.scs.2016.06.007

Riemenschneider C, Al-Raggad M, Moeder M, Seiwert B, Salameh E, Reemtsma T (2016) Pharmaceuticals, their metabolites, and other polar pollutants in field-grown vegetables irrigated with treated municipal wastewater. J Agric Food Chem 64:5784-5792. https://doi.org/10.1021/ acs.jafc.6b01696

Riva F, Zuccato E, Davoli E, Fattore E, Castiglioni S (2019) Risk assessment of a mixture of emerging contaminants in surface water in a highly urbanized area in Italy. J Hazard Mater 361:103-110. https://doi.org/10.1016/j.jhazmat.2018.07.099

Rizzo L, Krätke R, Linders J, Scott M, Vighi M, de Voogt P (2018) Proposed EU minimum quality requirements for water reuse in agricultural irrigation and aquifer recharge: SCHEER scientific advice. Curr Opin Environ Sci Heal 2:7-11. https://doi.org/10.1016/j.coesh.2017.12.004

Roberts J, Kumar A, Du J, Hepplewhite C, Ellis DJ, Christy AG, Beavis SG (2016) Pharmaceuticals and personal care products (PPCPs) in Australia's largest inland sewage treatment plant, and its contribution to a major Australian river during high and low flow. Sci Total Environ 541:1625-1637. https://doi.org/10.1016/j.scitotenv.2015.03.145

SCHER (2011) Scientific Committee on Health and Environmental Risks SCHER Scientific Committee on Emerging and Newly Identified Health Risks SCENIHR Scientific Committee on Consumer Safety SCCS Toxicity and Assessment of Chemical Mixtures. Eur Commision Toxic Assess Chem Mix 1-50. https://doi.org/10.2772/37863

Schmitt H, Blaak H, Kemper M, van Passel M, Hierink F, van Leuken J, De Roda Husman AM, van der Grinten E, Rutgers M, Schijven R, de Man H, Hoeksma P, Zuidema T (2017) Bronnen va antibioticaresistentie in het milieu en mogelijke maatregelen. 114. https://doi.org/10.21945/ RIVM-2017-0058 
Schulze S, Sättler D, Neumann M, Arp HPH, Reemtsma T, Berger U (2018) Using REACH registration data to rank the environmental emission potential of persistent and mobile organic chemicals. Sci Total Environ 625:1122-1128. https://doi.org/10.1016/j.scitotenv.2017.12.305

Schulze S, Zahn D, Montes R, Rodil R, Quintana JB, Knepper TP, Reemtsma T, Berger U (2019) Occurrence of emerging persistent and mobile organic contaminants in European water samples. 153:80-90. https://doi.org/10.1016/j.watres.2019.01.008

Shakir E, Zahraw Z, Al-Obaidy AHMJ (2017) Environmental and health risks associated with reuse of wastewater for irrigation. Egypt J Pet 26:95-102. https://doi.org/10.1016/j.ejpe.2016.01.003

Shenker M, Harush D, Ben-Ari J, Chefetz B (2011) Uptake of carbamazepine by cucumber plants a case study related to irrigation with reclaimed wastewater. Chemosphere 82:905-910. https:// doi.org/10.1016/j.chemosphere.2010.10.052

Singleton DR, Adrion AC, Aitken MD (2016) Surfactant-induced bacterial community changes correlated with increased polycyclic aromatic hydrocarbon degradation in contaminated soil. Appl Microbiol Biotechnol 100:10165-10177. https://doi.org/10.1007/s00253-016-7867-z

Siyal AA, Skaggs TH (2009) Measured and simulated soil wetting patterns under porous clay pipe sub-surface irrigation. Agric Water Manag 96:893-904. https://doi.org/10.1016/j.agwat.2008. 11.013

Sjerps RMA, Vughs D, van Leerdam JA, ter Laak TL, van Wezel AP (2016) Data-driven prioritization of chemicals for various water types using suspect screening LC-HRMS. Water Res 93:254-264. https://doi.org/10.1016/j.watres.2016.02.034

Smith HM, Brouwer S, Jeffrey P, Frijns J (2018) Public responses to water reuse - understanding the evidence. J Environ Manage 207:43-50. https://doi.org/10.1016/j.jenvman.2017.11.021

Sousa JCG, Ribeiro AR, Barbosa MO, Pereira MFR, Silva AMT (2017) A review on environmental monitoring of water organic pollutants identified by EU guidelines. J Hazard Mater 344:146-162. https://doi.org/10.1016/j.jhazmat.2017.09.058

Šteflová M, Koop S, Elelman R, Vinyoles J, Van Leeuwen CJK (2018) Governing non-potable water-reuse to alleviate water stress: the case of Sabadell, Spain. Water (Switzerland) 10:1-16. https://doi.org/10.3390/w10060739

Tal A (2016) Rethinking the sustainability of Israel's irrigation practices in the Drylands. Water Res 90:387-394. https://doi.org/10.1016/j.watres.2015.12.016

Thebo AL, Drechsel P, Lambin EF, Nelson KL (2017) A global, spatially-explicit assessment of irrigated croplands influenced by urban wastewater flows. Environ Res Lett 12. https://doi.org/ 10.1088/1748-9326/aa75d1

Thomaidi VS, Stasinakis AS, Borova VL, Thomaidis NS (2016) Assessing the risk associated with the presence of emerging organic contaminants in sludge-amended soil: a country-level analysis. Sci Total Environ 548-549:280-288. https://doi.org/10.1016/j.scitotenv.2016.01.043

Tran HN, You SJ, Hosseini-Bandegharaei A, Chao HP (2017) Mistakes and inconsistencies regarding adsorption of contaminants from aqueous solutions: a critical review. Water Res 120:88-116. https://doi.org/10.1016/j.watres.2017.04.014

Tran NH, Reinhard M, Gin KYH (2018) Occurrence and fate of emerging contaminants in municipal wastewater treatment plants from different geographical regions - a review. Water Res 133:182-207. https://doi.org/10.1016/j.watres.2017.12.029

UN-Water (2018) Sustainable development goal 6 synthesis report on water and sanitation 2018, Un. https://doi.org/10.1126/science.278.5339.827

USEPA (2012) Guidelines for water reuse. U.S. Agency Int Dev. 643. https://doi.org/EPA16251R921004

van der Waals MJ, Pijls C, Sinke AJC, Langenhoff AAM, Smidt H, Gerritse J (2018) Anaerobic degradation of a mixture of MtBE, EtBE, TBA, and benzene under different redox conditions. https://doi.org/10.1007/s00253-018-8853-4

van Wezel AP, van den Hurk F, Sjerps RMA, Meijers EM, Roex EWM, ter Laak TL (2018) Impact of industrial waste water treatment plants on Dutch surface waters and drinking water sources. Sci Total Environ 640-641:1489-1499. https://doi.org/10.1016/j.scitotenv.2018.05.325

Voulvoulis N (2018) Water reuse from a circular economy perspective and potential risks from an unregulated approach. Curr Opin Environ Sci Heal 2:32-45. https://doi.org/10.1016/j.coesh. 2018.01.005 
Wagner TV, Parsons JR, Rijnaarts HHM, de Voogt P, Langenhoff AAM (2018) A review on the removal of conditioning chemicals from cooling tower water in constructed wetlands. Crit Rev Environ Sci Technol 48:1094-1125. https://doi.org/10.1080/10643389.2018.1512289

Wang L, Hossen EH, Aziz TN, Ducoste JJ, de los Reyes FL (2020) Increased loading stress leads to convergence of microbial communities and high methane yields in adapted anaerobic co-digesters. Water Res 169:115155. https://doi.org/10.1016/j.watres.2019.115155

Winkler P, Kaiser K, Jahn R, Mikutta R, Fiedler S, Cerli C, Kölbl A, Schulz S, Jankowska M, Schloter M, Müller-Niggemann C, Schwark L, Woche SK, Kümmel S, Utami SR, Kalbitz K (2019) Tracing organic carbon and microbial community structure in mineralogically different soils exposed to redox fluctuations. Biogeochemistry 143:31-54. https://doi.org/10.1007/ s10533-019-00548-7

World Health Organization (WHO) (2006) Excreta and greywater in agriculture. Guidel. Safe use wastewater, excreta, greywater, vol II Wa, 204. https://doi.org/10.1007/s13398-014-0173-7.2

Yadav MK, Short MD, Aryal R, Gerber C, van den Akker B, Saint CP (2017) Occurrence of illicit drugs in water and wastewater and their removal during wastewater treatment. Water Res 124:713-727. https://doi.org/10.1016/j.watres.2017.07.068

Yang Y, Ok YS, Kim KH, Kwon EE, Tsang YF (2017) Occurrences and removal of pharmaceuticals and personal care products (PPCPs) in drinking water and water/sewage treatment plants: a review. Sci Total Environ 596-597:303-320. https://doi.org/10.1016/j.scitotenv.2017.04.102

Zapata N, Robles O, Playán E, Paniagua P, Romano C, Salvador R, Montoya F (2018) Low-pressure sprinkler irrigation in maize: differences in water distribution above and below the crop canopy. Agric Water Manag 203:353-365. https://doi.org/10.1016/j.agwat.2018.03. 025

Zhang Y, Sallach JB, Hodges L, Snow DD, Bartelt-Hunt SL, Eskridge KM, Li X (2016) Effects of soil texture and drought stress on the uptake of antibiotics and the internalization of Salmonella in lettuce following wastewater irrigation. Environ Pollut 208:523-531. https://doi.org/10.1016/ j.envpol.2015.10.025

Zhao W, Wang B, Wang Y, Deng S, Huang J, Yu G (2017) Deriving acute and chronic predicted no effect concentrations of pharmaceuticals and personal care products based on species sensitivity distributions. Ecotoxicol Environ Saf 144:537-542. https://doi.org/10.1016/j.ecoenv.2017.06. 058

Zheng G, Yu B, Wang Y, Ma C, Chen T (2020) Removal of triclosan during wastewater treatment process and sewage sludge composting - a case study in the middle reaches of the Yellow River. Environ Int 134:105300. https://doi.org/10.1016/j.envint.2019.105300

Open Access This chapter is licensed under the terms of the Creative Commons Attribution 4.0 International License (http://creativecommons.org/licenses/by/4.0/), which permits use, sharing, adaptation, distribution and reproduction in any medium or format, as long as you give appropriate credit to the original author(s) and the source, provide a link to the Creative Commons licence and indicate if changes were made.

The images or other third party material in this chapter are included in the chapter's Creative Commons licence, unless indicated otherwise in a credit line to the material. If material is not included in the chapter's Creative Commons licence and your intended use is not permitted by statutory regulation or exceeds the permitted use, you will need to obtain permission directly from the copyright holder.

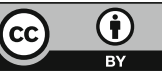

